Portland State University

PDXScholar

6-1-1968

\title{
Traits associated with choosing social work as a career
}

\author{
Helen Ellsworth \\ Portland State University \\ James B. Epley \\ Portland State University \\ Carolyn Hanson \\ Portland State University \\ Robert L. Morasch \\ Portland State University \\ Roberta Roth \\ Portland State University
}

See next page for additional authors

Follow this and additional works at: https://pdxscholar.library.pdx.edu/open_access_etds

Part of the Social Work Commons

Let us know how access to this document benefits you.

\section{Recommended Citation}

Ellsworth, Helen; Epley, James B.; Hanson, Carolyn; Morasch, Robert L.; Roth, Roberta; Rowe, Norma; Stowell, Richard H.; Swan, Fredrick H.; Wadsworth, Joanna M.; and Zeigler, Aurita, "Traits associated with choosing social work as a career" (1968). Dissertations and Theses. Paper 334.

https://doi.org/10.15760/etd.334

This Thesis is brought to you for free and open access. It has been accepted for inclusion in Dissertations and Theses by an authorized administrator of PDXScholar. Please contact us if we can make this document more accessible: pdxscholar@pdx.edu. 


\section{Author}

Helen Ellsworth, James B. Epley, Carolyn Hanson, Robert L. Morasch, Roberta Roth, Norma Rowe, Richard H. Stowell, Fredrick H. Swan, Joanna M. Wadsworth, and Aurita Zeigler 
$\frac{\text { HELEN ELLSWORTH, et al. for the } \frac{\text { MASTER }}{\text { (Degree) }} \text { in SOCIAL WORK }}{\text { (Name) }}$

Date thesis is presented APRII 18, 1968

Title TRAITS ASSOCIATED WITH CHOOSING SOCIAL WORK AS A

Abstract approved

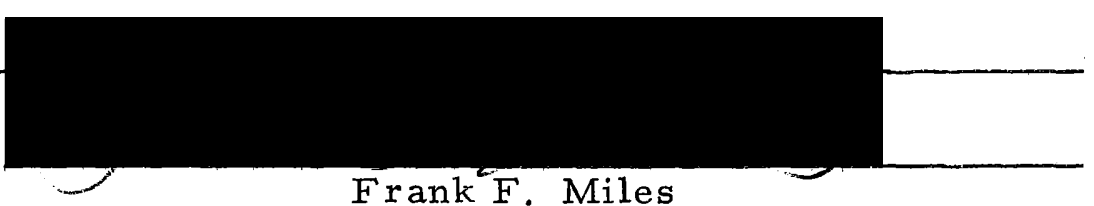

Frank F. Miles

This was a study of traits associated with the choice of social work as a career. Two samples of people from the metropolitan area of Portland, Oregon, who had shown an interest in social work were studied, together with the factors that influenced this interest. The traits and factors considered were substantially those examined by Arnulf M. Pins in Who Chooses Social Work, When and Why?

Traits measured by the Pins study of individuals who had gone on to graduate education in social work were held indicative of individuals most likely to become professional social workers. The Pins' questionnaire was slightly modified for appropriate application to the sample population of 150 taken from the files of Social Work Careers in Oregon, Incorporated, (SWC) and the sample of twentytwo Oregon Public Welfare employees attending the Oregon City Orientation Center (OC) in June 1967.

Examination of these traits and factors was undertaken to 
provide information for a more thorough understanding and an evaluation of characteristics associated with consideration of social service as a career, the future evaluation of policy direction and practice for recruitment efforts, the evaluation of potential students by schools of social work, the selection of agency personnel, and the contribution of knowledge in the field of social work about career patterns of nonprofessional and professional social workers.

Two general hypotheses guided the comparison of the Oregon samples with the Pins' findings:

the traits of the Oregon samples (SWC and OC) are not significantly. different from the Pins' sample,

there is no significant difference between the $O C$ and SWC samples with respect to independent variables influencing the time that a career in social work is chosen.

Descriptive and statistical inferential tests were used to analyze the data, No significant differences in the OC group and the Pins' sample of first year graduate students were revealed in the specific traits analyzed, i. e., undergraduate major of social science; previous work experience; time of awareness, consideration, and decision of choice of social work as a career; and the conception of the most important functions of social work.

The statistically significant differences between the SWC and the OC/Pins' groups were:

1) a larger number in the SWC group decided earlier on social work as a career, 
2) fewer in the SWC group took psychology courses,

3) a greater proportion of the SWC sample chose as their major reasons for considering social work "liking to work with people" and "the important contribution social work makes to individuals and society",

4) the SWC sample was not as predominantly committed to the casework method.

Both hypotheses were rejected as a whole, but with important distinctions drawn. It was found that the SWC sample and Pins' sample were significantly, different, but that the OC sample and Pins' sample were not significantly, different. The conclusions were that the people who contacted SWC appeared to be good prospects for entry into the field of social service at the bachelor's level and the OC sample at the master's level.

Generalizations about the social work community or those considering employment in the social work community should be cautiously drawn both because of the complexity of the association of traits and the limited size of the populations studied.

The major factors influencing individuals to enter the field of social work were direct work or volunteer experience in social work, college courses or instructors, and acquaintance with social workers. The study would have been enhanced by inclusion of more questions in the questionnaire that measured values and personality traits and by an examination of traits of a sample drawn from the general population. 


\title{
TRAITS ASSOCIATED WITH CHOOSING SOCIAL WORK AS A CAREER
}

by

Helen Ellsworth

James B. Epley Carolyn Hanson

Robert L. Morasch

Roberta Roth
Norma Rowe

Richard H. Stowell

Fredrick H. Swan

Joanna M. Wadsworth

Aurita Zeigler

\section{A GROUP PROJECT}

\author{
présented to \\ The School of Social Work and \\ the Graduate Council of \\ Portland State College
}

\author{
in partial fulfillment of \\ the requirements for the \\ degree of \\ Master of Social Work \\ June 1968
}




\section{APPROVED:}

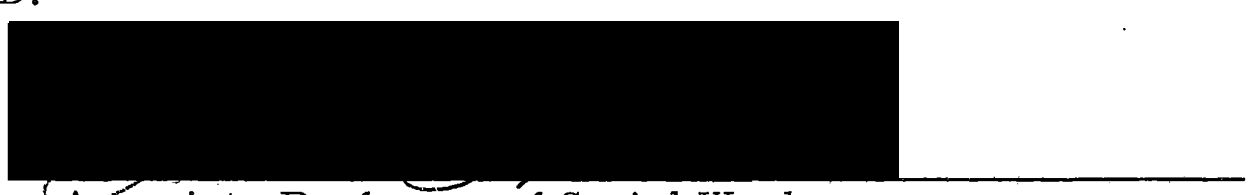

Associate Profes sor of Social Work

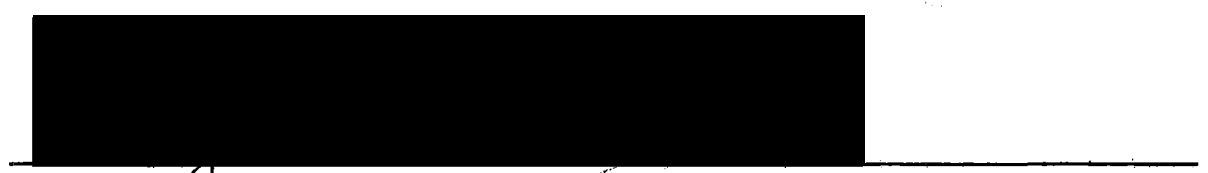

Dean, School of Social Work

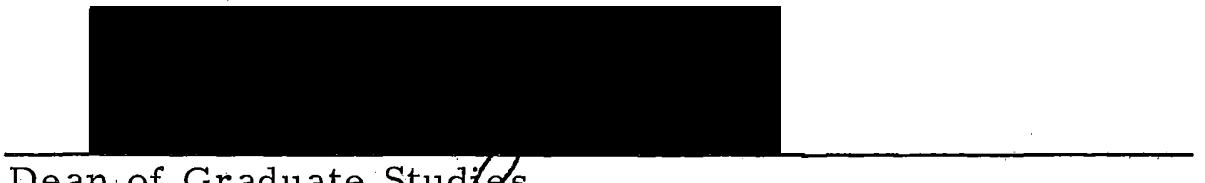

Dean of Graduate Studie's

Date thesis is presented eper 15,1968

Typed by Gwendolyn Hansen 
TABLE OF CONTENTS

Chapter

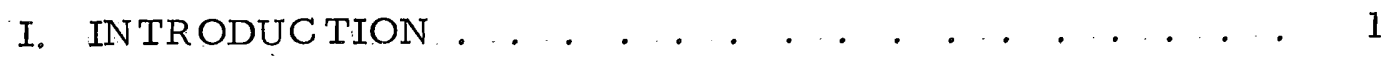

Background

Aims and Rationale

General Approach

Hypotheses

Population

Methodology

Chapter Notes

II. HISTORY OF SOCIAL WORK RECRUITMENT _ . . . 12

National

Oregon

Conclusion

Chapter Notes

III. A REVIEW OF THE LITERATURE . . . . . . . . 31

Search of the Literature

General Literature on Vocational Choice:

Major Significant Theories

Research on Career Choice in Social Work

Conclusion

Chapter Notes

IV. METHODOLOGY. . . . . . . . . . . . . 56

Procedure

Analysis of the Data

Chapter Notes 
Chapter

V. DESCRIPTIVE FINDINGS . . . . . . . . . 68

General Characteristics

Educational Background

Socio-Economic Background

Experience in Community Activities and

Social Work

Timing of Vocational Development

Factors Influencing Selection of Occupation

Influence of Social Work Careers

Summary

Chapter Notes

VI. SUMMARY AND ANALYTICAL FINDINGS . . . . . . 97

Descriptive and Analytical Findings

Age, Sex, and Marital Status

Race and Religion

Education

Socio-Economic Background

Work Experience

Choice of Social Work as a Career

Contact With Social Work Careers

Summary

Chapter Notes

VII. CONCLUSIONS . . . . . . . . . . . . . 109

BIBLIOGR APHY . . . . . . . . . . . . . . . . . 123

APPENDIX I Questionnaire . . . . . . . . 128

$\begin{array}{ll}\text { APPENDIX II } & \text { Summary of Tests of Significance } \\ & \text { Between Groups at .05 Level . . . . . . . } 140\end{array}$

APPENDIX III Summary of Tests of Significance

of Traits: Within the Sample at the

.05 Level . . . . . . . . . . 141 


\section{LIST OF TABLES}

Table

Page

1. Age Distribution . . . . . . . . . . . . . 69

2. Present Occupation - SWC . . . . . . . . . 70

3. Marital Status ... . . . . . . . . . . . . 71

4. Number of Children Under 21 Years of Age . . . . . 72

5. Religion . . . . . . . . . . . . 72

6. Area of Country Raised... . . . . . . . . . . . 73

7. Present Residence . . . . . . . . . . . . . 74

8. Schooling Completed . . . . . . . . . . . 75

9. Institutions Attended ..... . . . . . . 75

10. Grade Average During Last Two Years of School . . . . 76

11. Undergraduate Majors . . . . . . . . . . . . 77

12. Undergraduate Courses in Psychology and Sociology. . . . 78

13. Occupation of Father. . . . . . . . . . . . 79

14. Education of Parents . . . . . . . . . . 80

15. Extent of Activity in School or Community Organizations . 81

16. Leadership Activity in School or Community

Organizations ................ 81

17. Social Work Experience . . . . . . . . . . . . 82

18. Time of Awareness of Social Work as a Career.... . 83

19. Time First Considered Social Work as a Career . . . 83

20. Time of Choice of Social Work as a Career . . . . . 84 
21. Sources of Information About Social Work . . . . . 85

22. Influential Factors in Considering Social Work as a Career................ 86

23. Major Reasons for Considering Social Work . . . . . 87

24. Most Important Function of Social Work . . . . . 88

25. Method of Social Work Concentration . . . . . . 88

26. Other Careers Considered or Tried . . . . . . . . 89

27. Reasons for not Following Other Career . . . . . . 90

28. Factors Increasing Interest in Social Work . . . . . 91

29. Reaction to Contact with SWC . . . . . . . . 92

30. Actions Since First Contact with SWC . . . . . . . . 92

31. Factors Dis couraging Interest After Contact with SWC . . 93 


\section{CHAPTER 1}

\section{TRAITS ASSOCIATED WITH CHOOSING SOCIAL WORK AS A CAREER}

This is an exploratory study. of variables affecting decisions about the choice of social work as a career. The sample consisted of individuals who contacted Social Work Careers in Oregon, Incorporated, Portland, Oregon between September 1965 and August 1967 regarding employment in social work. This study also included the response patterns regarding career choice of individuals employed as Public Welfare caseworkers and in training at the State Public Welfare Orientation Center in Oregon City, Oregon during June of 1967. The traits studied in the Social Work Careers sample (1) ${ }^{1}$ and the Oregon City, sample (1) were compared with variables affecting social work career choice measured in a nationally based study done by Arnulf Pins in 1963.

\section{Background}

Major manpower shortages in the field of social work were created by an expansion and escalation of social welfare services (1)

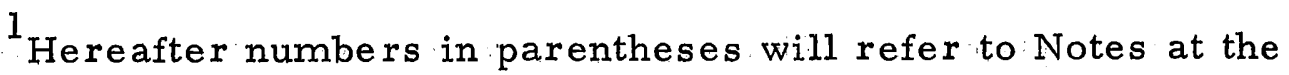
end of each chapter. 
in the United States, especially. after the Kennedy administration. The number of graduates from professional schools, projected at 23,000 for 1970, will probably be far short of the 84,000 graduate workers needed. (2) This prediction indicates the need for an increased number of graduate trained social workers. (1) Since graduate professionals (1) constitute less than $20 \%$ of those in the field, the necessity for wider recruitment is indicated.

The need for qualified professional personnel in Oregon will be affected by this manpower shortage. In recognition of current and future needs, Social Work Careers in Oregon, Incorporated, (1) was established during 1965 for the purpose of recruiting larger numbers of better qualified persons into the field of social welfare. (1) The program-was designed to; a) develop a comprehensive state-wide plan for recruitment; b) coordinate all social work recruitment efforts within the State; c) serve as a clearing house for the development, collection and dis semination of all types of recruitment materials; and d) answer inquiries about where to find social work positions in Oregon, but not to operate as a placement office. SWC intended to contact individuals and groups in grammar schools, high schools, colleges and various organizations where an interest in social work might be expressed. These contacts were aimed at partial alleviation of the manpower shortage.

In the process of recruiting new personnel into a given field, 
the goals of a profession should be considered. The recruitment of social welfare personnel by SWC has attempted to reconcile the selection of personnel with the goals of the social work profession and the particular agency in which the profession practices. Decisions made during a recruitment process influence the choice of personnel filling available positions, the amount and kind of education that is required for a specified job, and the desired personal characteristics of an employee assuming a position. The goals of the social work profession might be furthered if the recruitment process were able to focus more effectively on individuals having characteristics compatible with those goals.

A review of the literature revealed a study: by Arnulf Pins (3) dealing with career choice in social work. The current project made use of Pins' research as a basis for comparison. While the aims of the projects were similar, the populations differed in locale and educational background. The Project Group (1) was also.concerned with influential factors in social work career choice, but as they related to a population that had not necessarily committed itself to social work as a career and/or graduate professional education.

Pins' study, Who Chooses Social Work, When and Why?, focused on "Exploratory Study of Factors Influencing Career Choice in Social Work, " He examined the personal, socio-economic, and educational characteristics of social work students and made comparisons of the 
specific ways in which they are like and unlike other graduate students. His study objectives were to ascertain major factors influencing individuals who chose social work and graduate education, when they made this choice, and what factors influenced their decisions. His findings indicated: a) the value and effect of current recruitment programs; b) the mode of development of the process of occupational choice; c) the relationship between resources for information and factors influencing choice; and d) the time between learning about social work and the time of deciding upon the profession as a career. The similar aims of both projects made it pos sible to consider adapting Pins' questionnaire for the current study. Subsequently, permission:was obtained from Pins for the use and revision of the questionnaire so it could be applied to the local groups to be studied.

Traits measured by the Pins' study of those individuals who had gone on to graduate education in social work were held indicative of individuals most likely. to become professional social workers. Utilizing those traits as criteria for measuring characteristics possessed by individuals who were to become professional social workers, the traits of the OC sample and the SWC sample could be examined. The Project Group as sumed that those studied possessed the traits of the graduate social work student population and would be most likely to become profes sional workers. Identification of these traits would facilitate an examination of the recruitment program in 
terms of its focus on individuals likely to make social work their career choice.

Individuals in the OC sample had indicated an interest in social work by their employment choice. Information obtained from a comparison of the traits of the OC sample and the traits of the population of the Pins' study would provide supporting data for further evaluation of whether SWC recruitment efforts were effectively focused,

\section{Aims and Rationale}

The purpose of the project was to explore traits associated with entrance into social service as a career. The Project Group proposed to relate interest in social work to degree of knowledge about social work, interest one has or has not shown in the field, and actual experience in the field. Utilizing the preceding variables, the Project Group intended to study the influence SWC has had on individuals who contacted the program seeking career information and/or guidance.

Programs of recruitment for social service personnel could be benefited by expanded knowledge of those factors influencing social work career choice. Furthermore, knowledge of the relationships between influencing variables of career choice and job acceptance would add to the amount of information available to recruiters in schools of social work and in agencies employing social service 
personnel. Another intent of this study was to furnish historical information for a better understanding of the recruitment process in social work. Standard criteria for evaluating recruitment has not been established.

Another expectation was to obtain information regarding the similarities and differences between: influencing variables in a social work career choice in a local and national sample, professional and non-professional (1) social work roles, and short-term employees and those who choose social work as a career. Such a framework should offer some degree of common reference for further evaluation and would add to the articulation of fact and theory, particularly, with reference to the nationally based Pins' study. This project was undertaken with expectations of furnishing basic data for future evaluation of policy, direction, and practice of recruitment, with special reference to SWC.

\section{General Approach}

The Project Group concerned itself with specifying variables affecting social work career choice and the extent to which the se variables might be related. These aims were approached through the use of a questionnaire and statistical evaluation of the characteristics within the SWC and OC samples. 


\section{Hypotheses}

The hypotheses were put in null form for tests of significance:

$\mathrm{Ho}_{1}$ The traits of the Oregon sample (SWC and OC) are not significantly different from the Pins' sample.

$\mathrm{Ho}_{2}$ There is no significant difference between the $\mathrm{OC}$ and SWC samples with respect to independent variables influencing the time that a career in social work is chosen.

Since this was an exploratory study there were no prior expectations as to the results of the tests. The data were examined for possible relationships of paired or grouped variables, leading to a number of exploratory hypotheses.

\section{Population}

A population of 207 males and females who had contacted SWC was originally selected for study. Examination of personal data recorded by SWC resulted in three initial conclusions that preceded selection of the final sample, Because the only recorded contacts (1) were those that had been initiated by the individual, it was assumed that all those recorded had an interest in social work employment. Thus, those who specified they did not wish social work employment were eliminated from the sample. Those under the age of sixteen and over fifty: did not appear to receive similar opportunities for 
employment as those within this age range and were eliminated from the study, The recorded personal data was not complete on some individuals, and these were also excluded.

For the selection of the final sample, a table of random numbers was used to remove 57 individuals from the total group of 207 , leaving 150 for the sample.

The questionnnaire was also administered to a gro up of twentytwo caseworkers in the Oregon State Public Welfare Orientation Center at Oregon City. The total number of trainees at the Center participated on a voluntary;basis. The OC sample had expressed its interest in employment in the field of social work by nature of their position and presence at the training center.

\section{Methodology}

A random sample of contacts was taken from the files of SWC. A questionnaire, based on the Pins' questionnaire, was utilized; modifications were made to fit the locale and population. The traits of these individuals were to be compared with the traits of the OC sample and with the findings of the nationally based Pins' study. The questionnaire was first administered to the $O C$ sample at the training center. It was then administered by mail to the SWC s ample. 
The data was reviewed and tabulated to enable analysis by computer on the basis of selected traits which in the opinion of the Project Group were considered most important. 


\section{Chapter Notes}

1. The following definitions are listed in the order in which they appear in the text.

The sample selected for the current study: from the files of Social Work Careers in Oregon, Incorporated, will hereafter be referred to as the SWC sample.

Those individuals at the Oregon State Public Welfare Orientation Center in Oregon City, Oregon, in June of 1967 to whom the questionnaire was administered will hereafter be referred to as the OC sample.

Social Welfare Services will hereafter refer to the administration of Social Welfare to individuals, groups or communities. This term will be used in this study synonomously. with Social Work Services and Social Services.

Social Worker will refer to professional and non-professional practitioners engaged in Social Welfare Service.

Professional, when discussed in reference to the field of social work, will hereafter refer to those individuals having earned a Master's degree at an accredited school of social work.

The Social Work Careers in Oregon, Incorporated, in Portland, Oregon, will hereafter be referred to as SWC.

Social Welfare, when not discussed as a profession, will hereafter refer to those services involved in ". . . the full range of organized activities of voluntary and governmental agencies that seek to prevent, alleviate, or contribute to the solution of recognized social problems or to improve the well-being of individuals, groups or communities." Encyclopedia of Social Work, 15th Is sue, NASW, New York, N. Y., 1965, p. 3.

The Project Group will hereafter refer to the ten graduate social work students at Portland State College, Portland, Oregon, who between March 1967 and March 1968 conducted the exploratory study, "Traits Associated with Choosing Social Work as a Career."

Non-professional, when discussed in reference to the field of social work, will refer to those individuals who are engaged in the 
activity of providing social welfare services, but who have not completed graduate training at an accredited school of social work.

Contact, when discussed in reference to SWC, will hereafter refer to a recorded telephone and/or personal communication between an individual and SWC between September 1965 and August 1967.

2. M. Wittman, "The Implication of Social Welfare Needs in 1975 for Profes sional Education and Planning, "Social Service Review, XXXIX (1965), pp. 459-67.

3. Arnulf M. Pins, Who Chooses Social Work, When and Why? (New York: Council on Social Work Education, 1963). 
CHAPTER II

\section{HISTORY OF SOCIAL WORK RECRUITMENT}

Knowledge of factors that influence people to choose social work as a career is basic to framing techniques to attract, retain, and improve the quality of personnel in the social welfare field. Shortage of qualified personnel to perform welfare services has always been a concern of the profession. The increasing complexity of social problems arising from economic, technological, and wartime disturbances has created the demand for trained social workers.

The employment of people to work for social agencies has not always reinforced the field with qualified career-minded recruits. For lack of trained personnel, especially during crisis periods, workers were enlisted from many, sources. The frustration of unmitigated personnel shortage was endured for almost fifty years before the profession, social work schools, and social agencies began to formulate an integrated program of recruitment. Recruitment has had to deal with the problems of the social work image, inadequate salaries, and the striving for high standards. 
National

The first two decades of the twentieth century saw a new era of social welfare with the emergence of many private agencies competing for the services of the few professional workers. Job placement was done by individual agencies and through the Intercollegiate Bureau of Occupations in New York City. This first national job information center opened a social work division in 1912. (1) The majority of persons employed were without training. (2) The few graduate schools kept admittance standards low in an effort to increase enrollment. (3) Agencies experimented with summer training institutes which led to the establishment of full-time schools of social work. (4) Salaries were low and salary differential was slight between non-professional and professional workers. (5)

During World War I some agencies, such as the Red Cross, did their own recruiting. Others used the Bureau to handle their increasing needs. In 1917 the National Social Workers Exchange was organized for the placement of paid and volunteer workers. (6)

With the close of the war, increased attention was given to improved professional standards. Medical and psychiatric social workers formed their own associations and by 1919 were sending recruiters to college campuses. The Joint Vocational Service for Social Workers and Public Health Nurses performed employment 
and recruitment services. Recruitment was done on an individual basis by most schools of social work although the Association of Schools of Social Work was formed in 1919 with recruitment committee--a step toward coordination of recruitment. In 1921 the National Social Workers Exchange evolved into a professional group: the American As sociation for Social Workers. (7) Salaries moved upward moderately, but because of inflation, the 1925 median salary had only 3 per cent more buying power than the 1913 salary. (8) Salaries continued to rise slowly until 1930 when all vocations and professions faced income cuts.

The Federal Social Security programs enacted in the thirties made greater demands for personnel. New workers were often the jobless recruits from other fields. The demand created by a large number of public welfare jobs that did not require graduate training resulted in the introduction of many undergraduate programs for training social workers. By 1942 thirty-four institutions outside the accredited structure of social work schools formed the National Association of Schools of Social Administration. (9) By the early 1930's the American Association of Schools of Social Work had twentyeight member schools, with fifteen more providing some training on an undergraduate level. Of the total enrollment of approximately two thousand students only 10 per cent were full-time in graduate schools. (10) The Federal Government gave financial aid to one 
thousand social work students during 1934 and 1935 through the Federal Emergency Relief Administration. (11) Total student enrollment swelled to 5,044 in 1935 but by 1940 these same. As sociation schools had only 4,312 students. (12) Salaries rose slowly. (13)

The World War II years were beset with the problems of the thirties: employment of those who did not meet professional standards, low salaries in comparison to those offered by industry, and continued decline in school enrollment. The number of persons employed in social welfare grew from 72,528 in 1940 to an estimated 100,000 during the height of World War II. In 1942, only 10,602 social workers were members of the American Association of Social Workers, the largest professional organization. (14)

The heightened awareness of the profession of the need for graduate training in accredited schools did not stimulate school enrollment. From 1941 to 1942 there was a 13 per cent enrollment drop, with men accounting for nearly half of that percentage due to the war demand for manpower. (15) The students who did graduate were attracted to the private agencies because of their participation in wartime programs. Public agencies, without the support of federal scholarships as in the mid-thirties, had to find their personnel elsewhere. They: became hesitant to set standards that would necessitate study in a school of social work as a requisite for employment. Poor graduate school enrollment during these years was in part due 
to low salaries paid to graduate social workers and in part due to poor school location and recruitment programs. (16)

In 1942 new approaches to recruitment were considered by a committee representing the schools and professional associations. An inclusive national recruiting program was established in 1943: the Wartime Committee on Personnel in Social Services which had members from school and professional organizations. This Wartime Committee has been credited for stimulating recruitment activity on the local level. The G. I. Bill of Rights was responsible for increased enrollment in graduate schools during the period from 1945 to 1956. (17) With the expiration of the G. I. Bill in July 1956, enrollment of men dropped 27 per cent from the peak year of 1952 while enrollment of women dropped 10 per cent. (18) Comparis on of salaries of social workers with those in other fields seemed convincing evidence that low remuneration was a key, factor in the failure to recruit more men in to the field. (19)

Recruitment efforts were intensified by the social work schools and employing agencies. Schools resolved the problem of two separate accrediting bodies for social work. The National Association of Schools of Social Administration and the American As sociation of Schools of Social Work formed the Council on Social Work Education in 1952. (20) The Council realized the need for one central plan to guide local and national recruitment efforts and to eliminate gaps 
and duplications of independent recruitment programs. The Council joined in recruitment activities with the National Social Welfare Assembly and the National Committee on Social Work in Defense Mobilization. (21) Seven professional as sociations merged into the National As sociation of Social Workers (NASW) in 1955. The following year NASW put into effect, through their 142 local chapters and 22, 500 members, a program coordinated by the Council, (22) Starting in 1958, the Council began to receive feedback from these coordinated efforts in the form of more than 30,000 inquiries annually. (23) The recruitment committees of both the Council and NASW continued to hold joint meetings to coordinate efforts. In July, 1962, the Council and NASW established the National Commission for Social Work Careers--the central resource for accumulating and dispensing recruitment information. (24)

The Commission believed that effective recruitment could be carried on only at the local level and that potential social workers must be found and interested in their own communities. (25) By 1967 , with the assistance of a National Institute of Mental Health grant, the Commission's field service program helped organize twenty-four community and/or state Career programs. (26) The funding structure of each local program was determined by the local community, using a variety of methods.

The majority of the local Career programs had found the 
summer agency, experiences with college students to be their best recruitment tool. The Commission, during 1964 and 1965, focused on large segments of the population for recruitment into the field: persons seeking second careers and Peace Corps returnees. The Commission was concerned with the escalating number of workers needed for the future and the more slowly increasing number of professional graduates. While the original purpose of the Commission was to recruit persons to the social work profession, in 1966 the organization felt the focus should be to recruit qualified persons for social work positions as well as for social work education. The new theme emphasized varying educational needs for varying tasks and differential use of manpower. (27)

During 1961, the nation's graduate schools of social work'were operating at 93 per cent capacity. (28) A larger number of federal scholarships and more effective recruitment material became available. In 1964 , with 84 per cent of their graduate students receiving some financial aid, most graduate schools of social work had reached the saturation point. (29) The results of an informal survey showed that in December 1964 the majority of accredited schools were filled to capacity and most schools wanted to expand enrollment but lacked the funds to do so. (30) The proportion of master of social work degrees to the total number of masters' degrees in all fields had been declining since 1960. In 1965 the total masters' 
degrees awarded were 112,195 . Only 2,748 were given for social work. (31)

If the estimated number of social workers needed by 1970 was to be met, graduate school enrollment had to be quadrupled immediately (Refer to Page 2, Chapter I). (32) With the lack of funds to increase the capacity of existing schools and establish new ones at the rate necessary, other patterns and methods of education were developed. Experience had shown that federal support contributed substantially, to improvement of education. (33) Federal funds available through the 1967 amendments to the Social Security Act made possible the development, expansion, and improvement of educational facilities. The legislation provided that no les s than onehalf of the $\$ 5,000,000$ appropriated for fiscal 1969 must be spent on undergraduate programs. (34)

Many social work tasks do not require the services of a graduate social worker and may be accomplished by staff prepared at the baccalaureate level. New plans for undergraduate social welfare education were presented in special studies sponsored by the Council on Social Work Education. (35) In 1965, the total number of students enrolled in $232 \mathrm{schools}$ having defined programs in social welfare was 17,$067 ; 4,535$ students completed these programs in 1966. Of these 29.3 per cent entered graduate schools and 48.7 per cent entered social service employment. (36) 
Salaries of social workers remained below those of other professions. (37) The Family Service Association of America studied salary:improvement and recommended for 1968 the salary of $\$ 8,600$ for beginning caseworkers with a master's degree. (38)

\section{Oregon}

Education for social work in Oregon was subject to the growing pains experienced generally by schools throughout the United States. The Portland School of Social Work, which opened in 1919. under the auspices of the Department of Sociology of the University. of Oregon, closed in September 1932 when the legislature was unable to provide sufficient funds for its continuance. The graduate social work school established in 1943 by Marylhurst College had to be discontinued two years later because of low student enrollment. One graduate school for Oregon was to be firmly established. With the start of the Portland State College, School of Social Work in 1962 (39) three tasks were set: to establish a two year program leading to the Master of Social Work degree, to provide a certificate program for those working in the field and currently unable to attend graduate school, and to develop an undergraduate program in social services at Portland State College. (40)

By 1967 the graduate school had awarded eighty-two masters' degrees. The 1967-68 enrollment of seventy-seven students was 
close to the school's capacity. (41) The Certificate Program for training people working in the field graduated fifty students in the first class and had an en rollment of ninety-five Public Welfare staff members for the second year (1967-68) of the program. (42) The Public Welfare Commission anticipated that the program would result not only in increasing the skill of the staff in working with clients and community agencies but would strengthen the commitment of en rolled employee-students to Public Welfare. (43) During the period from $1962-1967$ there was about a 34 per cent turnover in caseworkers, with most persons leaving after their second or third year of employment. A report of the Oregon Public Welfare Commission, dated April 1963, showed that 109 employees had received Welfare grants for graduate social work education in the period from 1947 to 1962. After commitment agreements of two monthsi employment for each month in school were completed, only forty-six of these persons were still with the agency. (44)

Portland State College first offered courses in social service at the undergraduate level in 1966-1967 with twenty-five students enrolled. The number of students doubled the following year. An undergraduate program leading to a Certificate in Social Service was approved to begin in the academic year of 1968-1969. (45)

The University of Oregon received federal funds to establish an undergraduate School of Community Services and Public Affairs 
in 1967. The program was designed to prepare students for employment in public and private social agencies. (46) At least fifteen other undergraduate schools offered courses with social work content and some included field experience. The majority of the courses provided preprofessional instruction. (47)

Principal organizations active in Oregon's history of recruitment were the Oregon Public Welfare Commission, the local chapter of the National Association of Social Workers, the Portland Junior League, and Social Work Careers in Oregon, Incorporated.

The 1944-45, report published by the Oregon Public Welfare Commission mentioned, for the first time, the serious problem of personnel recruitment due to higher salaries offered by private industry. (48) In 1947, as a recruitment tool, the Commission began to offer graduate school scholarships to staff with the aid of federal money. In 1958 the Commission employed a personnel recruiter, with offices in Portland, to interview college students throughout the State. Between 1959 and June 1964, he answered 538 written inquiries from out-of-town students and arranged civil service tests at convenient locations. (49)

The Oregon Recruitment Committee of the National As sociation of Social Workers was organized in 1956. In addition to using the recruitment techniques of the national organization, the local chapter worked with the Portland Junior League Scholarship Selection 
Committee regarding persons interested in graduate study. Representatives of the chapter were active in stimulating community interest in the establishment of the graduate school of social work. (50) In 1957, organized recruitment of volunteer workers was done through the Central Volunteer Bureau created as a two year demonstration project by the Portland Junior League. (51) In 1966, the Junior League also sponsored a pilot program to interest high school juniors in social work with agency tours and individual interviews with social workers. The Executive Director of Social Work Careers in Oregon, Incorporated, was the resource person for the League in that program. (52)

Social Work Careers in Oregon, Incorporated (SWC), one of the twenty-four programs active in seventeen states in 1967 organized by the National Commission on Social Work Careers (53), officially began its work in September 1965. The plan to establish the recruitment program evolved from a workshop conference held October 21-23, 1964, at Dorchester House, Oceanlake (Lincoln City), Oregon. Forty-five persons representing a broad spectrum of community and state interests were invited to the conference.

The results of two surveys impressed the workshop participants with the personnel needs of community service agencies and with the public's limited understanding of the social work profession. The decision was made to establish an organization for the recruitment of 
qualified social work personnel and more accurately to interpret social work to the public, (54) Between September 1965 and August 1967, of the 272 SWC office interviews 207 were related to employment inquiries. The problem, as described by the SWC Executive Director, seemed to be not one of need for more interested persons but for more highly trained persons and the better utilization of personnel with different degrees of training. (55) The SWC program helped arrange placement opportunities for undergraduate students by setting up a registry: of planned agency experiences.

Although the original plan was for the agency to be statewide in scope, 75 per cent of the energies were centered in the Portland area. (56) Oregon showed a need for varied approaches to the interpretation of the profession of social work due to the widely differing conditions in the communities ranging from urban to rural.

\section{Conclusion}

This generic review of national and local recruitment to the field of social work reveals trends in three inter related areas: recruitment practices, training programs, and personnel standards.

Local independent activities of securing people to do social welfare jobs yielded to nation-wide cooperative tendencies within the associations of agencies, schools, and the helping professions. By the $1960^{\prime}$ 's these associations had integrated their efforts to recruit 
qualified people for positions and education into one national organization: the National Commission for Social Work Careers.

Training programs, first instituted by agencies, were formulated into accredited graduate programs but undergraduate schools still supplied the majority of welfare workers. The employees with baccalaureate degrees were responsible for 75 per cent of all social welfare services to clients in 1965. (57)

National organizations of schools, agencies, and professional workers enforced standards for the field by accreditation, membership, and certification requirements. (58)

The social welfare consciousness, reinforced by the War on Poverty programs of the Kennedy and Johnson administrations, required a fresh look at qualifications for social service personnel. What had to be faced was the clarification of the relationship between the professional social worker and the person without graduate training as well as administrative planning for differential use of manpower. The new dimension for recruitment efforts incorporated clear job descriptions and an awareness of factors that influence people to choose social work. With this knowledge more effective interpretation can be made for the benefit of employing agencies, for those qualified to do the work, and for the general public. 


\section{Chapter Notes}

1. Arnulf M. Pins, "Development of Social Work Recruitment: A Historical Review, "The Social Service Review, XXXIX (March, 1965), 53.

2. Esther Lucile Brown, Social Work as a Profession (New York: Russell Sage Foundation, 1942), p. 24.

3. Ibid., pp. 50-51.

4. Nathan Edward Cohen, Social Work in the American Tradition (New York: The Dryden Press, 1958), p. 119.

5. Brown, p. 168 .

6. Cohen, p. 137.

7. Pins, pp. 53-54.

8. Brown, p. 169. In 1913 the median salary was $\$ 840$; in $1925, \$ 1,517$.

9. Cohen, p. 198

10. Brown, pp. 90-92; Coheh, p. 147.

11. Cohen, p. 254.

12. Brown, p. 93.

13. Ibid., p. 171 .

14. Cohen, p. 254; Brown, p. 144, referred to census figures for 1940 which showed a total of 69,677 "social and welfare workers" who reported themselves as employed.

15. Cohen, p. 254.

16. Brown, pp. 96-98. Some schools were so.remote from areas of field work they could provide only a few students with fieldwork training. Several schools competed with others that were close-by while in some sections the re were vast areas with no accredited school of social work. 
17. Pins, pp. 55-56.

18. Cohen, pp. 275-276. In 1952, a high of 798 men were graduated from all schools of social work. Termination of the G. I. Bill benefits was in 1956-57.

19. Ibid., p. 297. Cohen compared social work salaries in the field of rehabilitation with salaries in fields which do not demand college training: social workers, $\$ 4,600$; railroad conductors, $\$ 7,681$; railroad brakemen, $\$ 6,239$; tool and die makers, $\$ 5,574$; automobile manufacturing, \$5, 400 .

20. Ibid., p. 282 .

21. Pins, p. 59.

22. Cohen, p. 282 .

23. Pins, p. 60 .

24. Cathryn S. Guyler, National Social Welfare Assembly, Minutes of Special Meeting on Recruitment, December 9, 1965, p. 1. (Processed)

25. Annual Review (New York: National Commission on Social Work Careers, March, 1964), p. 3.

26. Annual Review (1967), p. 13.

27. Virginia Ferguson, "Recruiting--For Social Work Positions," Annual Review (1966), p. 4.

28. Pins, p. 61 .

29. U. S. Department of Health, Education, and Welfare, Closing the Gap--in Social Work Manpower (Washington, D. C. : U. S. Government Printing Office, November, 1965), p. 50.

30. Ibid., p. 52 .

31. Annual Review (1967), p. 8; Annual Review (1966), p. 19, reported, "In June 1965, master's' degrees were conferred on 3,488 students, an increase of 14 per cent over 1964." 
32. Robert L. Barker and Thomas L. Briggs, "Trends in the Utilization of Social Work Personnel: An Evaluative Research of the Literature," Research Report Number Two, Utilization of Social Work Personnel in Mental Hospitals Project (New York: National As sociation of Social Workers, June, 1966), p. 16. (Processed)

33. Closing the Gap, p. 80 .

34. Annual Review (1967), p. 14; U. S. Public Law 90-248 HR 12080. 90 th Congress, December, 1967.

35. Herbert Bisno, The Place of the Undergraduate Curriculum in Social Work Education, The Social Work Curriculum Study, Vol. II (New York: Council on Social Work Education, 1959)

Sherman Merle, A Summary Report of Undergraduate Social Welfare Education in the United States: A Survey of Programs, Students, and Faculty (New York: Council on Social Work Education, 1966)

36. Merle, p. 10 .

37. Report of FSAA Personnel Committee, "Salary Policies and Ranges for Professional Positions: A Guide to FSAA Member Agencies," Approved by the Board of Directors, April 30, 1965 , pp. 4-10. (Processed)

38. "Salary Policies and Ranges," Approved by the FSAA Board of Directors, May, 1967, p. 8.

39. Barbara Nicholls, "Establishment of the School of Social Work, " Preliminary Draft (unpublished historical summary, Portland State College, School of Social Work, August, 1962). (Processed)

40. "Proposal for a Program Leading to a Certificate in Social Service," Portland State College, School of Social Work, Revised: October 9, 1967, p. 1. (Processed)

41. Admittance Records, Portland State College, School of Social Work files, 1967.

42. "The Certificate Program in the Social Services, "Progress report; A Section 1115 Project sponsored by the Oregon State Public Welfare Commission. The School of Social Work, Portland State College in cooperation with the Division of Continuing Education, 
State System of Higher Education located in Portland, Oregon (October, 1967), p. 7 .

43. Ibid., p. 1 .

44. "Educational Leave Program Results," Oregon Public Welfare Commission, Salem, Oregon, April 19, 1963. (Processed)

45. Daniel E. Jennings, Coordinator of Undergraduate Education for Social Work, Portland State College; in an interview on January 18, 1968, Dr. Jennings stated that final approval of the Program by the Board of Higher Education is expected the early part of 1968 .

46. "Proposal for Certificate in Social Service," p. 6.

47. "Helping Services: The Survey of Courses in Undergraduate Education, "from the files of Dr. D. Jennings, Portland State College, School of Social Work, 1967. (Processed)

48. State of Oregon Report of Public Welfare in Oregon for the Fiscal Year: July 1, 1944--June 30,1945, p. 12.

49. James Cunneen, former recruiter with the State Public Welfare Commission, interview, November 11, 1967.

50. Oregon Chapter of National Association of Social Workers, from 1956-57 files obtained from Allen Hatch, Chapter Chairman.

51. Helen Catlin, former director Central Volunteer Bureau, Portland, Oregon, interview, December 4, 1967.

52. Carolyn Selling, executive director SWC, interview, November, 1967.

53. Annual Review (1966), p. 13.

54. "In Preparation for the Workshop on Careers in Social Work, "NASW Newsletter, November, 1964. Reference made to survey by Carl Sandoz, director of Community Council, Portland, Oregon; and "The Image of Social Work, "from a copy of the speech delivered at Dorchester House Workshop, October 21, 1964, and which was the result of questionnaires administered by the School of Social Work. 
55. Carolyn Selling, personal interview, November, 1967.

56. "Recruit Whom for What?" NASW News, National As sociation of Social Workers, November, 1967, p. 13.

57. Closing the Gap, p. 81 .

58. Annual Review (1967), p. 7, reported that NASW supports laws for certification of social workers at two levels. In the Annual Review (1966), p. 20, the statement was made that in 1965, New York and Oklahoma passed statutes restricting the use of social work titles. Similar statutes were passed in California (1945) and Rhode Island (1961). 


\section{CHAPTER III}

\section{A REVIEW OF THE LITERATURE}

Plans were made in the early stages of the Social Work Careers Study to search the general literature dealing with factors bearing on career choice. A principal aim was to discover variables which might influence individuals in choosing social work as a career. Joint responsibility for this task was assumed by the Project Group as a whole, with individual as signments.

\section{Search of the Literature}

Material was sought under:

Books indexed under Careers, Professions, Professional Education, Professional, Vocational Guidance, Vocational Education, Vocation, Occupations, Social Services, and Social Work

Psychological Abstracts

Sociological Abstracts

Social Work Abstracts

Education Index

Business Periodicals

International Periodicals

Social Work Theses

Journals

Bibliographies

The terms "career," "vocation, " "occupation, " and "profession" have not been used as discreet entities in the literature. Definitions overlap and various writers use these words interchangeably. It was 
decided, then, that an attempt at differentiation would encumber rather than contribute to a search of the literature.

The design for the search of the literature included a specification of dates and of librany sources available. With the exception of the classical theories on vocational choice which began to appear in the $1950^{\prime} \mathrm{s}$, this chapter is limited to the period from 1960 to 1968. It was deemed necessary to include the earlie $\mathbf{r}$ significant theories as the foundation for the later studies. Regarding library sources available, the materials at Portland State College were the main source. The materials at the Social Work Careers office were also reviewed. The latter included information pertaining to the Social Work Careers organization locally and nationally, as well as some material on careers in social work. More than 300 items were reviewed, only the most relevant of which will be reported.

\section{General Literature on Vocational Choice: Major}

\section{Significant Theories}

Prior to the $1950^{\prime}$ s, vocational counselors had worked chiefly with tests of ability and inventories of interests on a pragmatic basis. Matching the traits of the individual with factors of the job was the method in common usage. In reviewing the general literature on vocational choice, a number of major theories began to emerge in the $1950^{\prime} \mathrm{s}$. 
The names of Ginzberg, Super, Roe, Tiedeman, Holland, and Bordin appear repeatedly. These writers formulated theories based on heuristic and empirical studies which have since become classics. These theories were based on findings from a number of fields - economics, sociology, psychoanalysis, psychology, and education. Some were based on data obtained from research studies while others were primarily speculative. All sought to explore those factors which cause people to engage in certain occupations. Hoppock described theoretical differences as follows:

Some of the authors explain occupational choice in terms of external, economic, sociological, and educational influences; others find their explanations in the conscious and unconscious internal motivations of the individual. There is sharp conflict on some points, considerable agreement on others. (1)

In 1951, Eli Ginzberg, an economist, with Ginsberg, Axelrad and Herma, published a monograph which called forth mixed reactions from other writers in the field and which stimulated the formulation of new theories. (2)

The Ginzberg Theory

Ginzberg's theory contained three elements. The first stated that occupational choice is a developmental process which typically takes place over a period of some ten years time. The second stated that this process is largely irreversible due to investments of time, money, and ego. The third stated that the process of occupational 
choice ends in a compromise between interests, capacities, values, and opportunities. Ginzberg then concluded that the process of decision-making could be analyzed in terms of three periods--those of fantasy, tentative, and realistic choices. In the fantasy period, the youngster thinks about an occupation in terms of his wish to be an adult. The tentative period begins at about age eleven and choices are determined largely by interest, then by capacities, and then by values. The period of realistic choices begins at about age seventeen and in this period exploratory, crystallization, and specification phases succeed each other over a period of approximately two years.

\section{Super's Theory}

Donald Super, a pioneer beginning his work in 1942 and one of the most referred-to writers in the field, (3) attacked Ginzberg's theory on the grounds of its failure to build adequately on previous work as well as on what he saw as its limitations. He stated his own theory in a series of ten propositions:

1. People differ in their abilities, interests and personalities.

2. They are qualified, by virtue of these characteristics, each for a number of occupations.

3. Each of these occupations requires a characteristic pattern of abilities, interests, and personality traits, with tolerances wide enough, however, to allow both some variety of occupations for each individual and some variety of individuals in each occupation. 
4. Vocational preferences and competencies, the situations in which people live and work, and hence their self concepts, change with time and experience (although self concepts are generally fairly stable from late adolescence until late maturity), making choice and adjustment a continuous process.

5. This process may be summed up in a series of life stages characterized as those of growth, exploration, establishment, maintenance, and decline, and these stages may in turn be subdivided into (a) the fantasy, tentative, and realistic phases of the exploratory stage, and (b) the trial and stable phases of the establishment stage.

6. The nature of the career pattern (that is, the occupational level attained and the sequence, frequency, and duration of trial and stable jobs) is determined by the individual's parental socioeconomic level, mental ability, and personality characteristics, and by the opportunities to which he is exposed.

7. Development through the life stages can be guided, partly by facilitating the process of maturation of abilities and interests and partly by aiding in reality testing and in the development of the self concept.

8. The process of vocational development is essentially that of developing and implementing a self concept: it is a compromise process in which the self concept is a product of the interaction of inherited aptitudes, neural and endocrine make-up, opportunity to play various roles, and evaluations of the extent to which the results of role playing meet the approval of superiors and fellows.

9. The process of compromise between individual and social factors, between self concept and reality, is one of role playing, whether the role is played in fantasy, in the counseling interview, or in real life activities such as school classes, clubs, part-time work, and entry jobs.

10. Work satisfactions and life satisfactions depend upon the extent to which the individual finds adequate outlets for his abilities, interests, personality traits, and values; they depend upon his establishment in a type of work, a work situation, and a way of life in which he can play the kind of role which his growth and exploratory experiences have led him to consider congenial and appropriate. (4) 
Ginzberg's and Super's Research Methods

Ginzberg's and Super's research methods differed markedly. The research of Ginzberg and his colleagues was cross-sectional. They interviewed sixty-four boys, aged eleven to twenty-four, from an upper socioeconomic level; as a check on this sample, they also interviewed seventy boys in a settlement house population and ten college girls. Interviews were highly, structured and about an hour in length.

Super felt that a longitudinal study based on a stable population would reveal more pertinent data regarding the variables affecting career choice, and would support his hypotheses of the five life stages and of occupational choice as being a process. He therefore headed the Horace Mann-Lincoln Institute of School Experimentation's Career Pattern Study begun in 1951. The population for this study was a group of 276 eighth and ninth grade boys attending school in Middletown, New York. Methods used were (1) tests, questionnaires, and ratings, (2) interviews with the boys, and (3) interviews with the parents of the boys.

\section{The Roe Theory}

Roe (5) took a different approach. Whereas Ginzberg and Super based their theories on genetic factors, socioeconomic factors 
and the organism interacting with its environment, Roe stressed the difference in parental handling of children and later adult behavior patterns which relate to vocational choices. Roe used Maslow's (6) hierarchy of prepotency of the individual's basic needs as the basis for her study. Maslow's basic needs are:

1. The physiological needs.

2. The safety needs.

3. The need for belongingness and love.

4. The need for importance, respect, self-esteem, independence.

5. The need for information.

6. The need for understanding.

7. The need for beauty.

8. The need for self-actualization.

She felt that the child's occupational choices would be determined in large part by the patterns of early experience with parents and the degree to which they met the eight needs listed above. She listed three major subdivisions in regard to the child's position in the family, emotional structure: as the center of attention, as avoided, or as accepted. She stated the se three positions would largely determine whether the child would be person-directed or non-person directed in his future vocational choice. She stated that "this is a speculative paper, and there is little direct evidence for the hypotheses which are sugg.ested." (7) 
The Tiedeman 'Theory

Tiedeman emphasized the process of decision in vocational development. He agreed with Super's outline of process but stated that "the structure of decision must be specified before investigations of the theory of vocational development can enter new phases. " (8)

He stated that "the compromise inherent in discovering and nourishing the area of congruence of person and society as expressed in an individual's vocational behavior is effected within a set of decision." (9) As a person matures, he makes decisions with regard to school, work, and life, and Tiedeman divides each decision into two periods--a period of anticipation and a period of implementation or adjustment. In the period of anticipation, exploration, crystallization, and choice takes place. In the period of implementation, induction, transition, and maintenance occur. Involved in the dynamics of the decision-making process is the fact that man both remembers and imagines, and this creates dependencies among decisions. In regard to memory, each decision made at an earlier time will effect a particular decision now in question. In regard to imagination, anticipatory behavior emerges with relation to several goals rather than with one alone. 
The Holland Theory

Holland, in 1959, published a paper (10) in which he criticized previous theories as being either too broad or too specialized. Super and Ginzberg fell in the former category; Roe, Bordin and Hoppock in the latter. He expressed a need for more comprehensive theorizing and attempted "to delineate a theory of vocational choice which is comprehensive enough to integrate existing knowledge and at the same time sufficiently close to observables to stimulate further research." (11)

Holland stated that at the time of vocational choice the person has a set of adjustive orientations or a distinctive "life style." $\mathrm{He}$ then correlated these "life styles" with the following six major occupational environments.

1. The Motoric Environment. Illustrative occupations are laborers, machine operators, aviators, farmers, truck drivers, and carpenters.

2. The Intellectual Environment. Illustrative occupations are physicists, anthropologists, chemists, mathematicians, and biologists.

3. The Supportive Environment. Illustrative occupations are social workers, teachers, interviewers, vocational counselors, and therapists.

4. The Conforming Environment. Illustrative occupations are bank tellers, secretaries, bookkeepers, and file clerks.

5. The Pursuasive Environment. Illustrative occupations are salesmen, politicans, managers, promoters, and business executives. 
6. The Esthetic Environment. Illustrative occupations are musicians, artists, poets, sculptors, and writers. (12)

Holland next described personality traits corresponding with the six occupational environments. For example, he saw the person with the supportive orientation as follows:

Persons of this orientation prefer teaching or therapeutic roles, which may reflect a desire for attention and socialization in a structured, and therefore safe, setting. They possess verbal and interpersonal skills. They are also characterized as responsible, socially oriented and accepting of feminine impulses and roles. Their chief values are humanistic and religious. They are threatened by and avoid situations requiring intellectual problem-solving, physical skills or highly, ordered activities, since they prefer to deal with problems through feeling and interpersonal manipulations of others. Persons of this class are best typified as orally dependent in the sense of being verbal, feminine, and dependent. (13)

He concluded that the individual's ability to fit himself into the most suitable occupational environment is based upon degree of "intelligence + self evaluation."

The Bordin, Nachmann and Segal Theory

Bordin, Nachmann, and Segal related their study (14) published in 1963 to Holland's, but pointed out that whereas Holland forced occupations into particular classifications, they found it more meaningful to establish a series of pivotal personal dimensions, forming a matrix into which occupations could be mapped. They professed a psychoanalytic orientation toward personality dynamics and set forth 
three preliminary as sumptions:

1. A continuity in development which links the earliest work of the organism in food getting and mastery of the body and coping with the stimulations of the environment to the most highly abstract and complex of intellectual and physical activities.

2. That the complex adult activities retain the same instinctual sources of gratification as the simple infantile ones.

3. That although the relative strengths and configurations of need are subject to continual modification throughout the life span, their essential pattern is determined in the first six years of life. The seeking out of occupational outlets of increasingly precise appropriateness is the work of the school years, but the needs which will be the driving forces are largely set before that time. (15)

The personal dimensions, set up in chart form, were traced to infantile physiological functions, which could account for all the gratifications work offers. Occupations could then be described in terms of the relative strengths of these dimensions. As an example:

The second cluster of dimensions have to do with the teeth and the satisfactions to be had from biting, chewing and devouring. We would assume that these impulses are translated in the adult into the use of cutting and grinding and drilling tools-that these activities are delegated first from teeth to fingers, then to knives and saws and drills, and finally to biting and cutting words and ideas. (16)

\section{Research on Career Choice in Social Work}

As early as 1932, Niebuhr described the "average modern social worker" as "... very often of the type in whom traditional religion no longer awakens interest, who is affronted by the intellectual obscurantism in which conventional orthodoxy is clothed, or 
perplexed by the intellectual problems which the religious world view faces in our modern scientific culture; but he is probably. engaged in social work precisely, because that vocation is to him the most logical means of expressing his mission to mankind. ..." (17)

Since Niebuhr's general description, many studies have focused on characteristics and traits of the social worker and the elements of his career choice. Intelligence, interest, and aptitude tests have been developed; chance, cultural, social and economic factors have been studied; the significance of social status, attitudes, and values have been explored; and with the development of vocational choice theory, developmental and psychoanalytical approaches have been formulated.

\section{Kadushin's Survey}

Kadushin, in 1957, published one of the first general surveys of factors which influence individuals to choose social work as a career. (18) He drew together eight areas of general agreement among the major theories and then analyzed particular factors. In regard to Supe $r^{\prime}$ s idea that role playing based on identification was essential to the compromise process which determines occupational choice, he pointed out that

social work is at a disadvantage as far as early determination of choice is concerned. Social work has low visibility for most elementary, high school and college students. It is difficult to 
identify with an occupation unless one has the opportunity for personal contact. (19)

In considering why people choose social work, Kadushin listed the following reasons from a polling of some 1200 students entering schools of social work in 1949: (20)

The principal reasons, in order of frequency were: 1) a desire to work with people--50\%;2) offers job security-$21 \%$; 3) desire to work toward improvement of social and economic conditions--15\%;4) interest in having a better understanding of the behavior, attitudes and relationship of people--12\%; and 5) consider personal qualifications best suited to social work- $-8 \%$, (21)

He stated, too, that "on a personality typology analysis social work students show greater concern than others with being liked, wanted, needed, approved of and appreciated." (22)

He suggested three possibilities concerning those who choose social work as a career:

Differences in background require differential emphasis: emphasis on the internal satisfactions is necessary to attract students of professional middle class parents; emphasis on the intrinsic satisfactions--the white collar nature of the occupation, professional status, etc., is legitimate in interesting students of minority groups.

Choice of social work requires that the person be willing and able to complete work toward a degree. Whatever factors militate against going to college will militate against a choice of social work as a career.

Women are more likely to be drawn to social work than men. The kinds of responses that the good worker is called upon to make are regarded as feminine--tender, gentle, warm, accepting, non-aggressive responses. (23) 
In regard to when choice is made, Kadushin suggested that it comes

at a relatively late date based on the premise

that social work does not require a definite commitment either in high school or college. People majoring in a wide variety of fields may still obtain social work jobs upon graduation from college and apply for entrance to schools of social work. In addition the satisfactions of social work are more likely, to appeal to a more mature group. (24)

Kadushin next discussed the factor of retention in the field and

postulated from "a number of studies" that

1) graduates of schools of social work are more likely. to develop professional longevity than non-graduates; 2) even professional education does not 'immunize' women against the lure of the role of wife and mother; 3) salary is a crucial determinant in retaining men in social work; and 4) the 'problem of recruitment' may not be a problem of recruitment but rather a problem of retention. (25)

He concluded with the following much-quoted summary:

The statistical fiction woven from the studies indicates that the person most likely to be susceptible to the advances: of the social work recruiter is: a female of above average intelligence, of professional or middle class parents, living in a large northern city, whose occupational values and interests revolve around a desire to work with people in an effort to help them through the use of verbal skills. (26)

\section{Minnes ota's Studies}

The School of Social Work at the University of Minnesota has focused research attention on aspects of career choice in social work under the stimulation of its director, John C. Kidneigh. These include studies by. Lundberg, Oren, Francel and McCornack. 
The Lundberg Study

Lundberg compared social work students from four universities

with fifth year-students in the fields of education, engineering, law,

library science, nursing, and psychology, using questionnaires.

Findings indicated that

social work students in this study, were found to have similar academic interests with students in education, nursing, and psychology. Their salary expectations paralleled thos ef students in nursing, library science, and education. In verbal intellectual abilities they did not differ significantly, from the combined central group.

In their cultural and social origin, social work students were similar to the students in the other six professions in nationality, race and social class.....

Social workstudents . ... were found to have made their career choice of a profession at a later period of life than had the students in the other six professions. They alsofelt less parental support in their choice at least from mothers.

The social work students were found to be more liberal ... in their view than the control group on the following points: 1) anti-democratic attitudes, 2) ethnocentrism, 3) political-economic conservatism, and 4) interpretation of traditional family, ideology. (27)

\section{The Oren Study}

Oren constructed an instrument for the measurement of social workers' attitudes associated with aptitude for interpersonal relationships. Two groups of social workers were contrasted on the basis of relatively: good and relatively poor aptitude for interpersonal relationships. The instrument consisted of 184 opinion statements, the ideational content being related to a theoretical framework of social work 
principles and values. A comparative analys is between the two groups was provided by allowing for varying degrees of agreement or disagreement on a scale for each item. (28)

This research gives some empirical evidence to support the conviction held by many that social workers with the most favorable set of attitudes toward people and social situations tend to be the best social workers. Further research is needed to determine the permanency of attitudes. (29)

The Francel Study

Francel's study was directed at isolating factors as sociated with the successful outcome of professional training for social work. In using the faculty, of a school of social work to judge which graduates could be expected to be highly: successful practitioners and which could be expected to be marginal, an attempt was made to determine factors associated with success. Findings suggested that

undergraduate grade averages were found to be highly as sociated with the criteria of success as measured by this study. ... Other characteristics of success as ociated included emotional maturity, capacity for change, capacity to be self-critical, and capacity to accept the criticism of others. These findings confirm the belief that personality characteristics are important to the success of the individual social worker. (30)

\section{The McCornack Study}

McCornack, in a study of approximately 1200 social workers, attempted to deline ate interests of male and female social workers as they differed from men and women in general. He found that "a strong 
liking for verbal activities and a dislike of the physical sciences seem to be distinctive interests of social workers. . . ." $\mathrm{He}$ concluded that both men and women social workers tended to dislike conservative and athletic people and added that "what women social workers seem to like most is attending conferences and conventions." (31)

The Gockel Study

The National Opinion Research Center sent questionnaires to 40,000 seniors on thirty-five campuses in 1961. eliciting their career aspirations, immediate post-graduate plans, reactions to courses and other college experiences, occupational values, and other information, including the usual background data. The study was longitudinal in that follow-up questionnaires were sent out in 1962,1963 , and 1964 to compare change over a period of time. Gockel, as a sub-study, us ed this material with specific reference to those students who aspired to social work as their career field. (32) He found a large expansion of social work aspirants occurring during the college years, with relative stability later on. During the college period, the re was a large defection in choice of social work, but an even larger recruitment, which resulted in a net gain. Recruits were relatively disinterested in the occupational values of freedom from supervision, opportunities to be original and creative, and money, but were 
strikingly attracted by the opportunity to work with people. They were generally low on the Academic Performance Index. The proportion of men to women retaining interest in social work increased greatly during the time period but never reached the distribution for all students of $60 \%$ male and $40 \%$ female, Retention was higher for men than women; that is, though relatively few men initially choose social work, a relatively high proportion retained interest over these time periods. Retention was positively associated with interest in people; income was not found to be a significant factor. As sociation with other variables was not conclusive.

\section{The Pins Study}

In 1963 Pins published his exploratory study of factors influencing career choices in social work. (33) This study is particularly significant for the social work careers study in that the questionnaire devised by Pins was utilized, with alterations and modifications to fit a different population, and his findings were used as one basis of comparison.

Pins' study had a three-fold objective. It sought:

1. To ascertain data about (a) who chooses social work and graduate professional education, (b) when social work students make their career choice, and (c) what factors influence this decision.

2. To consider the implications of the findings for agencies, schools of social work, the National Association of Social 
Workers, local social work career committees, and the Council on Social Work Education, as the findings relate to recruitment and admission procedures for professional education.

3. To raise more clearly defined questions for future research on career choices in social work. (33)

The following broad questions were selected as the major focus of Pins' study:

1. What is the present composition of the student body in schools of social work in terms of age, sex, religion, race, marital status, socio-economic background, academic preparation, organizational activity, and work experience?

2. Has the composition of the student body in schools of social work (in terms of the characteristics identified above) changed in the past ten years?

3. At what stage of life or education do individuals choose social work as their career?

4. What factors, if any, have major influence on individuals in their choice of a social work career?

5. Are there any differences among students who concentrate their studies in the casework, group work, and community organization methods in terms of general characteristics (identified in question 1) or in terms of when and why they chose social work as a career? (33)

Pins' population consisted of all full-time, first-year students who entered schools of social work in the United States and Canada in the fall of 1960. All sixty-three accredited schools participated and 2931 completed questionnaires were returned. This represented a 98.7 per cent sample:

The scope of this review precludes a detailed reporting of Pins' 
findings. Instead, selected highlights of the data in relation to key

questions one, three and four are summarized in the following excerpts

from the sixth chapter. (33)

Sex, Age and Marital Status. Among the social work students in the 1960-1961 academic year there were more women than men students. However, over two-fifths of all students were male. Almost 70 per cent of the students were under thirty years of age and only 10 per cent were forty years or older. Almost half of the student body were or had been married. A greater proportion of the women than the men were single as they entered social work education. More than half of those married had one or more children.

Race and religion. The religious distribution of students in social work education in 1960 was unlike the distribution of the three major faiths in the population of the United States. There were fewer Protestant students and more Jewish students in schools of social work than in the religious affiliations of the total population. The proportion of Catholic students was almost equal to their representation in the country. The percentage of Negro students in social work was somewhat higher than their proportion in the population.

Geographic origin. Almost half of all first-year students in schools of social work in the fall of 1960 had lived most of their lives on the Eastern Seaboard. Over 40 per cent lived in states in the Middle Atlantic and Southeastern part of the United States. Another 20 per cent came from states in the Central portion of the country. Relatively few students lived in the far North, the Southwest, or in New England.... More than a third of all the students, lived in large cities with populations over 500,000 .

Education. About half of all the students completed their undergraduate studies in a privately-sponsored institution of higher learning, while 43 per cent ... attended a public college or university. Only 3 per cent of the students were graduates of teachers colleges and fewer than 1 per cent received their college education at institutions outside the United States and Canada. The vast majority, of students, 71 per cent, had an average grade of " $\mathrm{B}$ " in their junior and senior years at college; $14 \%$. . . had a "C plus" average and 
only, 3 per cent had a grade average of "C" or less. On the other hand, 11 per cent of the students achieved an "A" average in their last two years of college. The social sciences were chosen by 62 per cent of the students as their college majors. All other pos sible undergraduate majors each represented less than 10 per cent of the social work students. Social welfare and business were next in order but were selected far less frequently.... 5 per cent of all students had no undergraduate psychology courses and 11 per cent never studied sociology in college.

Socio-economic background. Most students... came from lower-middle class homes, as indicated by their fathers ${ }^{1}$ occupations and their parents' income and education. A smaller but not insignificant group came from both upper and lower income families. As a group their socio-economic background was higher than the national average.

Work experience. Over 80 per cent of the ..... students studied had direct paid or volunteer work experience in social work. Fifty-nine per cent actually worked on a full-time basis for six months or more in a paid social work position. Thirtysix per cent... had held paid summer positions and another 20 per cent had been employed during the year on a part-time basis. Almost half of the students, 45 per cent, had at one time served as volunteers in a social agency. . ..

Organizational experience. Social work students, as a group, were very active in community and college organizational life. Over 33 per cent considered themselves "quite active," and 27 per cent . ... "frequently" held leadership positions. Only 11 per cent "hardly ever" served as officers or committee chairmen in the groups to which they belonged.

How and When do Students Learn About Social Work?

As a group, social work students became aware of this field at a relatively, late stage in their education. Direct contact with social work and social workers as well as college courses and instructors were the major sources of information for students about social work. 


\section{When do Social Work Students Decide on Their Career?}

A final social work career decision was made relatively late and for most students did not seem to be their first choice. Most of the first-year students .... did not seriously consider or decide on a social work career until their last year in college or after graduation. Many waited a year or more .... before entering graduate professional education. Most students considered or tried another career and some first obtained graduate degrees in fields other than social work.

What Factors Influence the Career Choice of Social Work Students?

The major sources of information about social work---work experience, college courses and instructors, and social workers themselves--were also the factors reported by students to have influenced them most to select a social work career. Parents, relatives, teachers and friends generally did not oppose . . . choice of a social work career, although only about half of the students .... reported that their choice was approved by these people. Most students who had considered or tried other careers indicated that they switched because they felt they were better suited for social work than for their first choice or other possible occupations. In general, students chose social work because they valued its goals and functions and found it to coincide with their assessment of their own interests and skills. Very few were influenced by social work's monetary or status remunerations.

\section{$\underline{\text { Conclusion }}$}

In this chapter an attempt has been made to give an overview of general theories of vocational choice as well as to describe research projects directed toward is olating factors influencing the selection of social work as a career choice, with emphasis on Pins' study. The aim has been to place in perspective the objectives and findings of the Social Work Careers Study. 
Chapter Notes

1. Robert Hoppock, Occupational Information: Where to Get It and How to Use It in Counseling and Teaching. (New York: McGrawHill, 1957), p. 86.

2. Eli Ginzberget al. , Occupational Choice, an Approach to a General Theory (New York: Columbia University Press, 1951).

3. Super's Contributions include The Dynamics of Vocational Adjustment (New York: Harper and Brothers, 1942); The Psychology of Adjustment (New York: Harper and Brothers, 1942); Vocational Development: A Framework for Research (New York: Columbia University Teachers Bureau of Publications, 1957); and The Vocational Maturity of Ninth Grade Boys (New York: Columbia University Teachers Bureau of Publications, 1960).

4. Donald E. Super et al., Vocational Development: A Framework for Research (New York: Columbia University Teachers Bureau of Publications, 19.57) pp. 14-15.

5. Anne Roe, "Early Determinants of Vocational Choice," in Vocational Development and Career Development, ed. by Herman J. Peters and James C. Hansen (New York: The Macmillan Company, 1966), pp. $110-18$.

6. A. H. Maslow, Motivation and Personality (New York: Harper and Brothers, 1954) p. 80-98.

7. Roe, op. cit., p. 113.

8. David Tiedeman, "A Theory of Vocational Choice," in Vocational Development and Career Development, ed. by Herman J. Peters and James C. Hansen (New York: The Macmillan Company, 1966), p. 119.

9. Ibid.

10. John Holland, "Occupational Choice: A Conceptual Framework, "Ibid. , p. 119.

11. Ibid., p. 127.

12. Ibid., p. 128. 
13. Ibid. , p. 130 .

14. Edward S. Bordin, Barbara Nachmann, and Stanley J. Segal, "An Articulated Framework for Vocational Development, " Ibid. , pp. 156-71.

15. Ibid. , p. 160 ,

16. Ibid. , p. 165 .

17. Reinhold Niebuhr, The Contribution of Religion to Social Work (New York: Columbia University Press, 1932), p. 61.

18. Alfred Kadushin, "Determinants of Career Choice and Their Implications for Social Work, "Social Work Education, VI (No. 2, 1958), pp. 17-26.

19. Ibid. , p. 19.

20. American Association of Schools of Social Work, "Why Students Choose Social Work as a Career, "No. 1098, New York, undated.

21. Kadushin, op. cit. , p. 19.

22. Ibid.

23. Ibid., p. 20.

24. Ibid.

25. Ibid, , p. 22.

26. Ibid.

27. John C. Kidneigh and Horace W. Iundberg, "Are Social Work Students Different?" Social Work, III (July, 1958), 59-60.

28. Anne Oren, "The Construction of an Instrument for the Measurement of Social Work Attitudes Associated with Aptitude for Interpersonal Relationships, "University of Minnesota, 1957, unpublished $\mathrm{Ph}$. D. dissertation, cited by Edward W. Francel, "The Individual: Key Factor in Welfare Manpower, "in Manpower in Social Welfare: Research Perspectives, ed. by Edward Schwartz (New York: National As sociation of Social Workers, 1966), p. 83. 
29. Ibid. , p. 84 .

30. Edward Francel, "Factors Associated with the Successful Outcome of Professional Training for Social Work, " unpublished Ph. D. dissertation, University of Minnesota, Ibid., p. 87.

31, R. McCornack and J. C. Kidneigh, "The Vocational Interest Patterns of Social Workers, "Social Work Journal, XXXV (October, 1954), pp. $161-63$.

32. Galen L. Gockel, "Social Work as a Career Choice," in Manpower in Social Welfare: Research Perspectives, ed. by Edward E. Schwartz (New York: National Association of Social Workers, 1966), pp, 89-98.

33. Arnulf M. Pins, Who Chooses Social Work, When and Why? (New York: Council on Social Work Education, 1963). 


\section{METHODOIOGY}

The project group of ten graduate students first met in March of 1967. The group discussed the problem "who chooses social work as a career, and why?" The merits of different research approaches were explored. In the initial phase a review was made of recruitment in other fields, the influence of prestige and status as factors in choosing a career, and what had already, been done in researching social work as a career choice. Each member noted his readings in duplicate and from these a central file was developed. From this search the group became aware of the study by Arnulf Pins. (1) A replication of Pins' work was selected as the method of study. A letter was written to Pins requesting permission to use his work in a replication study and permission was granted.

Approximately 90 per cent of those studied were a cross section of individuals who had contacted Social Work Careers in Oregon, Incorporated. A contact with SWC was defined as encompassing those individuals who had initiated a personal interview with SWC personnel. The remaining portion of the population represented the Oregon City Orientation Center sample. The OC sample was a group of employed individuals attending the Orientation Center of the Oregon Public 
Welfare Commission.

SWC was chosen because it was an accessible sample of people who had contacted a social work careers information center but were not necessarily committed to a career in social work. Commitment to a career in social work as used in this study means either being permanently employed in a social work position or engaged in some activity for the primary purpose of gaining permanent social work employment. The director of SWC agreed to cooperate in allowing access to the data on record. In April a sub-committee of the project group visited the SWC office, talked with the director, searched the files, and reported back to the project committee. As a result of the visit, the decision was made to limit the population of study to those people who had contacted SWC on their own initiative. This decision was made because the files were not complete as to name and address of those people who had been contacted by personnel on the staff of the SWC office.

It was decided to use the period from September 1965 to August 1967 because the SWC office was better established by this time, files were more complete, and the probability of locating recent SWC contacts was greater.

OC was chosen as a sample because it provided a group of individuals who were currently employed in social work, had selected social work as a career, and were a readily accessible sample. 
Another reason for selecting. OC was its use as a means of comparison with the SWC sample and with the Pins sample.

The OC sample numbered twenty-two. Based on past yearly enrollment figures, this was approximately: $14 \%$ of the total enrollment at the Orientation Center in any given year.

\section{Procedure}

In the spring of 1967 a tentative time schedule was prepared to meet limitations imposed by the curriculum:

1. Spring 1967: Reviewing of literature; revising questionnaire; administering a pre-test; finalizing questionnaire.

2. Summer 1967: Administration of questionnaire; follow-up of questionnaire; review of literature.

3. Fall 1967: Analyzing data; review literature; writing chapter reports.

4. Winter 1968: Analyzing data; preparing final report.

The members of the Project Group selected chapter as signments on which they wished to: work in the spring of 1967. Areas which were searched with respect to the literature were psychological periodicals, abstracts and textbooks, educational periodicals and textbooks, thesis material, international periodicals and abstracts, and social work abstracts applicable. The search of the lite rature went back to 1960 unless older material was cited in recent works as 
having made a significant contribution to the field. As each subcommittee completed a rough draft of a chapter, it was presented to the total group for comment, criticism, evaluation, and revision. The central problem in assessing factors which lead to the choice of a career was devising an instrument to identify and measure those factors which influence an individual in his particular career choice. A well structured questionnaire was envisioned by the group as the most appropriate method of obtaining this information. Seldom is one survey regarded as sufficient; usually repetitions are considered desirable in order to check the results and also to form a basis for estimating the precision obtained. (2) This was the basis for replicating the Pins's study.

The Pins' questionnaire was designed to survey, graduate students in social work. The questionnaire was modified because some of Pins' questions were not applicable to the samples being studied. The Project Group operated as a committee in arriving at decisions effecting changes in the questionnaire.

The questionnaire was pre-tested with an undergraduate group enrolled in a social work course at Portland State College in order to gain experience in its administration and to point out needed modifications for future use. As a result of pre-testing, the questionnaire was revised. Changes in the questionnaire involved deleting those questions specifically designed by Pins to elicit responses from graduate 
social work students. Questions having to do with demographic factors or with financial aid while attending school were modified. Questions were added to measure the effect of SWC.

The questionnaire was administered to the twenty-two persons in the OC group. This group was enrolled in the June 1967 session at the orientation center. The twenty-two persons represented the total number who were enrolled at the time. It was later found that the group, while approximately $14 \%$ of the 1967 classes at the center, probably was over representative of more recent graduates. The primary purpose in studying this group was to provide a sample for comparative purposes between persons who had made a strong commitment toward a career in social work and the main study group. One change was made in the questionnaire prior to mailing to the SWC sample. The change involved the addition of questions relating to interest in social work. A copy of the questionnaire in its final form is included as Appendix I.

The SWC sample was drawn from the population who had contacted SWC between September 1965 and August 1967. The Project Group decided that those recorded as over fifty years of age would be deleted from the sample because opportunities for employment in this age category are limited, unless the individual is experienced. A decision was made to eliminate those who had not as yet reached their sixteenth birthday when it was discovered that the primary reason 
for these contacts was summer employment according to information available in the SWC office. After eliminating those under 16 and those over 50 , the resultant population numbered 207 . The resultant population was sequentially numbered from 1 to 207 . The decision was made that a manageable sample would number 150. A table of random numbers was used to remove 57 questionnaires from the total population of 207, leaving 150 for the sample. In summary, the SWC sample numbered 150 individuals between the ages of 16 and 50 who had initiated a contact with SWC.

Prior to mailing the questionnaire, a card was sent to the SWC sample explaining the purpose and importance of the questionnaire they would soon receive. The questionnaire was mailed in September of 1967. A cover letter was sent to explain the purpose of the questionnaire. A stamped self-addressed envelope was included to facilitate returning the questionnaire to the project committee. In October 1967, thirty-three follow-up telephone calls were directed to those whose telephone number could be found to facilitate return of the questionnaire. Of these people, six requested that a new questionnaire be sent to them as they had lost or misplaced the original. Letters were mailed to the remaining twenty-five people who could not be reached by telephone, requesting their cooperation and enclosing a card for them to return indicating if they were going to mail the completed questionnaire or if they wanted another one sent. 
Of these people, two requested additional questionnaires. By December 1967 ninety-two completed questionnaires had been received. The Project Group decided that further efforts to obtain completed questionnaires would not result in a significant number of returned questionnaires, based largely on the fact that only two completed questionnaires had been received from follow-up efforts.

Responses to the questionnaire were tabulated, with one person reading the response and another entering the response on a tabulation sheet. The statistical committee verified the tabulation sheets by re-reading the information contained on the questionnaire and checking with the data included on the tabulation sheets.

The tabulation sheet was designed to facilitate key punching of the data onto cards so that it could be processed by computer. Openended responses were listed from the original questionnaire and analyzed using descriptive techniques. The purpose in including openended responses on the questionnaire was to make the number of responses to each question manageable from the standpoint of number of responses and to gain insight into areas not conceived of by the Project Group so that areas for further study might be identified.

The data cards were verified for accuracy of key punching by printing out the punched data and comparing this print out to the tabulation sheets. This process was accomplished in pairs with one person reading the print out and the other pers on verifying the read number 
with the tabulation sheet. All mistakes required repunching a data card for the appropriate questionnaire when a mistake was discovered. The data cards were incorporated into a computer program designed to total the responses and compute the percentage of responses in any given category. The data acquired from this phase of the computer program provided the statistical committee with approximately 2,400 items of descriptive data.

Duplicates of the data cards were obtained using a card duplicator. These cards were used in another computer program to determine the observed occurrence of particular types of responses in a given category. This information was used to complete the matrices used in the computation of the Chi-square tests of significance. A computer was used to compute the Chi-squares.

After gathering the data, the next step was to test the hypotheses concerning the nature of the relationship of the observations. Two major hypotheses were tested using inferential statistics. The first hypothesis tested was:

Ho 1 The traits of the Oregon sample (SWC and OC sample) are not significantly different from the Pins sample.

The purpose in testing this hypothesis was to determine whether specific traits of the Oregon sample were the same as those in the Pins study. The specific traits analyzed were: undergraduate major, number of psychology courses completed, number of sociology courses 
completed, reasons for considering social work as a career and conceptions of the most important functions of social work. The second hypothesis tested involved an evaluation of several independent variables having to do with the timing and sequence of events. The second hypothesis was stated:

$\mathrm{Ho}_{2}$ There is no significant difference between the OC and SWC sample with respect to independent variables influencing the time that a career in social work is chosen.

Specific traits tested with respect to $\mathrm{Ho}_{2}$ were: the time decided on social work as a career, time first considered social work as a career and time of awareness of social work as a career. A summary of the findings are found in Chapter VI, Table 32.

\section{Analysis of the Data}

The statistical committee used descriptive and statistical inferential tests in analyzing the data. Descriptive methods were used to draw general inferences about the sample and to describe the traits of the sample with respect to socio-economic traits, experience, timing of vocational development, and influences in selection of a vocation, as variables. The Chi square test of significance was used as the inferential statistical test in analyzing the data. The Chi-square test was used as a test to determine when two or more frequency distributions, such as Pins, OC, and SWC, varied 
sufficiently to indicate that they did not come from the same or a common population. In addition, the Chi-square test was used as a test of association, that is: to test whether or not there was an association between two or more variables when the observed frequencies were clas sified according to two or more variables. Null hypotheses were tested and accepted or rejected at the .05 level. Significant relationships, implications and conclusions were explored and developed by the statistics committee when the Chi square value was significant and the relationship did not occur by chance.

A primary purpose of the study was to identify significant traits which influence a person making a choice of social work as a career. The project group felt that certain traits were important in selecting a career in social work which could be determined by comparing these traits between the SWC and the OC samples. Some of the traits investigated were related to: interest in social work; experience in social work; and the period of his life in which an individual decides on social work as a career. The traits relating to these areas were selected as a result of group consensus by reviewing the questionnaire. Another purpose of the study was to examine the differences in the three population samples. The Project Group anticipated that the re would be significant differences between the Pins/OC population and the SWC sample. It was anticipated that thes e differences would exist because the Pins and the OC sample had made a relatively strong 
commitment to a career in social work while the SWC sample had not necessarily done so. Another area where a fundamental difference in the populations was anticipated was between the SWC/OC sample and the Pins sample resulting in factors described as regional in origin. In conclusion, the total group recorded and submitted sugges tions to the statistics committe for the concluding chapter. The summary of the findings, suggestions for further study and implications for recruitment are included in Chapter VII. 


\section{Chapter Notes}

1. Pins, Arnulf M. Who Chooses Social Work: When and Why? New York: Council on Social Work Education, 1963.

2. Wilson, Jr., E. Bright, An Introduction to Scientific Research. McGraw-Hill Book Co., Inc., New York. 1952.

3. Arkin, Herbert, and Colton, Raymond R. Tables for Statisticians. 2d ed. New York: Bames and Noble, 1963. 


\section{CHAPTER V}

\section{DESCRIPTIVE FINDINGS}

The purpose of this project was to look for traits associated with people choosing social work as a career. Traits, or sets of traits, in two samples were studied using a questionnaire based on one developed by Arnulf Pins in a study of first-year students in graduate schools of social work in 1960. (1) One sample was drawn from people who had contacted Social Work Careers in Oregon, Incorporated (SWC) during 1965 and 1967. These people indicated sufficient interest in social work that their contact was recorded. The second consisted entirely of people entering various positions in social work with the Oregon Public Welfare Commission. They attended the Oregon Public Welfare Orientation Center at Oregon City (OC) in June of 1967.

This chapter reviews selected traits of the two samples. The traits are described in the areas of general characteristics, educational background, socio-economic background, experience in social work and community activities, timing of vocational development, factors influencing selection of occupation, and influence of SWC. 


\section{General Characteristics}

Sex

In recent years the percentage of men employed in social work was about $40 \%$. $(2,3)$ The two samples studied showed a significant decrease from this figure. Only $17 \%$ of the SWC sample and $22 \%$ of the OC sample were men. In the SWC sample, 22 people were employed in some field of social work at the time the questionnaire was completed. Of these, only four, or $18 \%$, were men.

TABLE 1

AGE DISTRIBUTION

\begin{tabular}{lrrrrr}
\hline & \multicolumn{2}{c}{ SWC } & & \multicolumn{2}{c}{ OC } \\
\cline { 2 - 5 } Age & $\mathrm{N}$ & $\%$ & & $\mathrm{~N}$ & $\%$ \\
\hline 15 to 19 years & 12 & 13 & 0 & 0 \\
$20-24$ & 35 & 38 & 7 & 31 \\
$25-29$ & 23 & 25 & 5 & 22 \\
$30-34$ & 3 & 3 & 3 & 13 \\
$35-39$ & 3 & 3 & 1 & 4 \\
$40-44$ & 5 & 5 & 2 & 9 \\
$45-49$ & 7 & 7 & 1 & 4 \\
50 years and older & $4 \mathrm{a}$ & 4 & 3 & 13 \\
& 92 & $\overline{98} \mathrm{~b}$ & $\overline{22}$ & $\overline{96} \mathrm{~b}$ \\
\hline
\end{tabular}

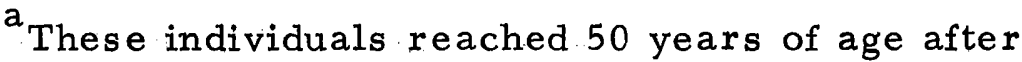
selection of sample.

${ }^{b}$ The percentages do not always total $100 \%$ due to rounding off of individual percentages by the computer. 
Both samples were quite young. Seventy-six per cent of the SWC sample, and $53 \%$ of the OC sample were under 30 years of age. In the SWC sample the larger percentage under 30 years of age could be attributed to the number of students.

TABLE 2

"PRESENT OCCUPATION" - SWC

\begin{tabular}{|c|c|c|}
\hline \multirow[b]{2}{*}{ Occupation } & \multicolumn{2}{|c|}{ SWC } \\
\hline & $\mathrm{N}$ & $\%$ \\
\hline $\begin{array}{l}\text { Professional person (eg. doctor, } \\
\text { teacher, lawyer, minister, } \\
\text { scientist) }\end{array}$ & 32 & 34 \\
\hline $\begin{array}{l}\text { Proprietor, manager, or official } \\
\text { (eg. owner, banker, army officer, } \\
\text { city or union official) }\end{array}$ & 3 & 3 \\
\hline $\begin{array}{l}\text { Clerical, sales and kindred worker } \\
\text { (eg. bookkeeper, sec., insurance } \\
\text { agent, salesman) }\end{array}$ & 13 & 14 \\
\hline Farmer or Farm manager & 1 & 1 \\
\hline $\begin{array}{l}\text { Skilled or semi-skilled worker } \\
\text { (eg. craftsman, barber, jeweler, } \\
\text { bartender, plumber) }\end{array}$ & 3 & 3 \\
\hline Unskilled worker (eg. laborer, maid) & 1 & 1 \\
\hline Hous ewife & 10 & 10 \\
\hline Student & 25 & 27 \\
\hline Unemployed & $\begin{array}{r}4 \\
-\end{array}$ & $\begin{array}{r}4 \\
\end{array}$ \\
\hline & 92 & 97 \\
\hline
\end{tabular}


All of the OC sample were employed in social work and would be in the professional person group. In the SWC sample about two-thirds of the professional person group was employed in social work. Fiftysix per cent of the sample were employed, and an additional $27 \%$ gave their occupation as student. The students had not completed their education and entered an occupation.

TABLE 3

MARITAL STATUS

\begin{tabular}{lrrrrr}
\hline & \multicolumn{2}{c}{ SWC } & & \multicolumn{2}{c}{ OC } \\
\cline { 2 - 3 } \cline { 6 - 6 } Marital Status & $\mathrm{N}$ & $\%$ & & $\mathrm{~N}$ & $\%$ \\
\hline Single, never married & 43 & 46 & 4 & 18 \\
Married & 40 & 43 & 16 & 72 \\
Widowed & 0 & 0 & 0 & 0 \\
Separated or Divorced & 9 & 9 & 2 & 9 \\
\hline
\end{tabular}

A general as sumption has been that social work was a career for women, usually single. The OC sample found that 12 , or $71 \%$, of the women were married. Four of the five men were married. Single people made up $46 \%$ of the SWC sample.

Fourteen per cent of the SWC sample and $35 \%$ of the OC sample had two or more children. The large number of single people in the SWC sample was reflected in the number of people having no children under 21 years of age. 
TABLE 4

NUMBER OF CHILDREN UNDER 21 YEARS OF AGE

\begin{tabular}{lrrrrr}
\hline & \multicolumn{2}{c}{ SWC } & & \multicolumn{2}{c}{ OC } \\
\cline { 2 - 3 } \cline { 5 - 6 } Children & $\mathrm{N}$ & $\%$ & & $\mathrm{~N}$ & $\%$ \\
\hline None & 61 & 66 & 11 & 50 \\
One & 11 & 11 & 2 & 9 \\
Two & 7 & 7 & 6 & 27 \\
Three & 3 & 3 & 1 & 4 \\
Four or More & 4 & 4 & 1 & 4 \\
No Response & 6 & 6 & 1 & 4 \\
& - & - & - & - \\
\end{tabular}

TABLE 5

RELIGION

\begin{tabular}{lrrrrr}
\hline \hline & \multicolumn{2}{c}{ SWC } & & \multicolumn{2}{c}{ OC } \\
\cline { 2 - 3 } \cline { 5 - 6 } Religion & $\mathrm{N}$ & $\%$ & & $\mathrm{~N}$ & $\%$ \\
\hline Catholic & 19 & 20 & 3 & 13 \\
Jewish & 6 & 6 & 0 & 0 \\
Protestant & 59 & 64 & 14 & 63 \\
Other & 2 & 2 & 1 & 4 \\
None & 6 & 6 & 4 & 18 \\
& -92 & -98 & 22 & 98 \\
\hline
\end{tabular}

The majority in each sample were Protestant. There was little representation of minority groups. In the SWC sample, "Catholic" included two Greek Orthodox; "Protestant, "two Mormon and four Unitarian; "Other, " one Buddhist and one agnostic. In the OC sample there was one Mormon and one agnostic. 
Race

The SWC sample was $96 \%$ white. There were two Negroes and one oriental in the remainder of the sample. All of the OC sample were white. There was a large Negro population in the Portland metropolitan community that was not represented in either sample.

TABLE 6

AREA OF COUNTRY RAISED

\begin{tabular}{|c|c|c|c|c|}
\hline \multirow[b]{2}{*}{ Area } & \multicolumn{2}{|c|}{ SWC } & \multicolumn{2}{|c|}{ OC } \\
\hline & $\mathrm{N}$ & $\%$ & $\mathrm{~N}$ & $\%$ \\
\hline New England & 3 & 3 & 0 & 0 \\
\hline Middle Atlantic & 3 & 3 & 1 & 4 \\
\hline Southeast & 3 & 3 & 0 & 0 \\
\hline Southwest & 0 & 0 & 0 & 0 \\
\hline Central & 6 & 6 & 3 & 13 \\
\hline Northwest & 4 & 4 & 2 & 9 \\
\hline Far West & 70 & 76 & 14 & 63 \\
\hline Canada & 2 & 2 & 1 & 4 \\
\hline \multicolumn{5}{|c|}{ Country other than US } \\
\hline or Canada & 0 & 0 & 0 & 0 \\
\hline \multirow[t]{3}{*}{ No Response } & 1 & 1 & 1 & 4 \\
\hline & - & - & - & - \\
\hline & 92 & 97 & 22 & 97 \\
\hline
\end{tabular}

Both the SWC and the OC samples were composed of people who were living in Oregon at the time the samples were drawn. The majority of them had been raised in the Far West.

Seventy-nine per cent of the SWC sample were living in areas with a population over 50,000. The OC questionnaire did not include 
this category. The addresses of the SWC sample indicated that the majority were from the Portland Metropolitan Area. SWC reached few people outside of this area.

\section{TABLE 7}

PRESENT RESIDENCE

\begin{tabular}{lrrrrr}
\hline & \multicolumn{2}{c}{ SWC } & & \multicolumn{2}{c}{ OC } \\
\cline { 2 - 3 } \cline { 5 - 6 } Residence & $\mathrm{N}$ & $\%$ & & $\mathrm{~N}$ & $\%$ \\
\hline Rural Farm & 3 & 3 & 3 & 13 \\
Rural non-farm & 0 & 0 & & 0 \\
Under 5, 000 & 3 & 3 & & 1 & 4 \\
5, 000 to 50,000 & 13 & 14 & 17 & 77 \\
50, 000 and over & 73 & 79 & & a & \\
No Response & 0 & 0 & & 1 & 4 \\
& - & - & & \\
& 92 & 99 & 22 & 98 \\
\hline
\end{tabular}

${ }^{a}$ Not in OC questionnaire

\section{Educational Background}

Sixty per cent of the SWC sample had completed four or more years of college. An additional $20 \%$ completed one or more years. Only $2 \%$ did not complete high school. Twenty-nine per cent were full-time students at that time. A college degree was required of the OC sample as a condition of employment by the Oregon Public Welfare Commission. Twenty-one per cent of the OC sample had completed one or more years of college beyond the normally required four years for a degree. 
TABLE 8

SCHOOLING COMPLETED

\begin{tabular}{|c|c|c|c|c|}
\hline \multirow[b]{2}{*}{ Years of Schooling } & \multicolumn{2}{|c|}{ SWC } & \multicolumn{2}{|c|}{$\mathrm{OC}$} \\
\hline & $\mathrm{N}$ & $\%$ & $\mathrm{~N}$ & $\%$ \\
\hline 9 Years & 0 & 0 & 0 & 0 \\
\hline $10 \quad 11$ & 2 & 2 & 0 & 0 \\
\hline $11 \quad " 1$ & 0 & 0 & 0 & 0 \\
\hline $12 \quad " 1$ & 13 & 14 & 0 & 0 \\
\hline $13 \quad 11$ & 7 & 7 & 0 & 0 \\
\hline $14 \quad " 1$ & 8 & 8 & 0 & 0 \\
\hline $15 \quad 11$ & 5 & 5 & 0 & 0 \\
\hline $16 \quad 11$ & 41 & 44 & 17 & 77 \\
\hline $17 \quad 11$ & 11 & 11 & 3 & 13 \\
\hline 18 or More & 5 & 5 & 2 & 8 \\
\hline \multirow[t]{2}{*}{ No Response } & 5 & 5 & 0 & 0 \\
\hline & 92 & 101 & 22 & 98 \\
\hline
\end{tabular}

TABLE 9

INSTITUTIONS ATTENDED

\begin{tabular}{|c|c|c|c|c|}
\hline \multirow[b]{2}{*}{ Institution } & \multicolumn{2}{|c|}{ SWC } & \multicolumn{2}{|c|}{$\mathrm{OC}$} \\
\hline & $\mathrm{N}$ & $\%$ & $\mathrm{~N}$ & $\%$ \\
\hline \multicolumn{5}{|c|}{ Private liberal arts college, } \\
\hline $\begin{array}{l}\text { City, county or state } \\
\text { college, not part of } \\
\text { university }\end{array}$ & 14 & 15 & 6 & 27 \\
\hline Private University & 6 & 6 & 3 & 13 \\
\hline Public University & 24 & 26 & 9 & 40 \\
\hline Teachers' College & 2 & 2 & 1 & 4 \\
\hline \multicolumn{5}{|l|}{ Institution outside US } \\
\hline or Canada. & 0 & 0 & 0 & 0 \\
\hline Other & 7 & 7 & 0 & 0 \\
\hline \multirow[t]{2}{*}{ No Response } & 21 & $\underline{22}$ & 0 & $\underline{0}$ \\
\hline & 92 & 97 & 22 & 97 \\
\hline
\end{tabular}


The question for Table 9 was designed to show the type of undergraduate institution from which a degree was obtained. The SWC sample answered the question although they might not have received a degree. Public universities accounted for the largest number in each sample. "City, county or state colleges... "was the next largest category in the OC sample. "Private liberal arts colleges.." was the second largest category in the SWC sample.

TABLE 10

GRADE AVERAGE DURING LAST TWO YEARS OF SCHOOL

\begin{tabular}{|c|c|c|c|c|}
\hline \multirow[b]{2}{*}{ Grade } & \multicolumn{2}{|c|}{ SWC } & \multicolumn{2}{|c|}{$\mathrm{OC}$} \\
\hline & $\mathbf{N}$ & $\%$ & $\mathrm{~N}$ & $\%$ \\
\hline A & 1 & 1 & 1 & 4 \\
\hline A- & 9 & 9 & 3 & 13 \\
\hline $\mathrm{B}+$ & 21 & 22 & 6 & 27 \\
\hline $\mathrm{B}$ & 12 & 3 & 3 & 13 \\
\hline$B-$ & 16 & 17 & 7 & 31 \\
\hline $\mathrm{C}+$ & 9 & 9 & 1 & 4 \\
\hline C or lower & 8 & 8 & 0 & 0 \\
\hline \multirow[t]{3}{*}{ No Response } & 16 & 17 & 1 & 4 \\
\hline & - & - & $\overline{20}$ & $\overline{0}$ \\
\hline & 92 & 96 & 22 & 96 \\
\hline
\end{tabular}

Pins found that $71 \%$ of his sample fell in the " $B$ " average $(B+$, B. B-) category. (4) The OC sample also had $71 \%$ with a reported "B" average. Eighty-eight per cent of the OC sample and $59 \%$ of the SWC sample reported a grade average of " $\mathrm{B}$ " or better during the last two years of school. 
TABLE 11

UNDERGRADUATE MAJORS

\begin{tabular}{|c|c|c|c|c|}
\hline \multirow[b]{2}{*}{ Major } & \multicolumn{2}{|c|}{ SWC } & \multicolumn{2}{|c|}{$\mathrm{OC}$} \\
\hline & $\mathrm{N}$ & $\%$ & $\mathrm{~N}$ & $\%$ \\
\hline $\begin{array}{l}\text { Social Science (eg. psychol } \\
\text { ogy, sociology, anthropol } \\
\text { ogy, history, economics) }\end{array}$ & - & 54 & 13 & 59 \\
\hline $\begin{array}{l}\text { Social Work or Social } \\
\text { Welfare }\end{array}$ & 6 & 6 & 0 & 0 \\
\hline $\begin{array}{l}\text { Physical science (eg. } \\
\text { physics, chemistry) }\end{array}$ & 1 & 1 & 1 & 4 \\
\hline $\begin{array}{l}\text { Biological Sciences (eg. } \\
\text { zoology) }\end{array}$ & 0 & 0 & 0 & 0 \\
\hline English and Literature & 3 & 3 & 3 & 13 \\
\hline Foreign Languages & 3 & 3 & 0 & 0 \\
\hline Mathematics & 1 & 1 & 0 & 0 \\
\hline Fine Arts & 3 & 3 & 0 & 0 \\
\hline Education & 6 & 6 & 2 & 9 \\
\hline Business & 2 & 2 & 0 & 0 \\
\hline Other & 7 & 7 & 3 & 13 \\
\hline Did not major & 1 & 1 & 0 & 0 \\
\hline No Response & 11 & 11 & 0 & 0 \\
\hline & $\overline{92}$ & $\overline{98}$ & $\overline{22}$ & $\overline{98}$ \\
\hline
\end{tabular}

There was no direct preparation for social work through an undergraduate social work major in the OC sample. However, $6 \%$ of the SWC sample had a social work major. Over $50 \%$ of the SWC sample and the OC sample majored in the social sciences. 
TABLE 12

UNDERGRADUATE COURSES IN PSYCHOLOGY AND SOCIOLOGY

\begin{tabular}{|c|c|c|c|c|c|c|c|c|}
\hline \multirow[b]{3}{*}{ Number of Courses } & \multicolumn{4}{|c|}{ Psychology } & \multicolumn{4}{|c|}{ Sociology } \\
\hline & \multicolumn{2}{|c|}{ SWC } & \multicolumn{2}{|c|}{$\mathrm{OC}$} & \multicolumn{2}{|c|}{ SWC } & \multicolumn{2}{|c|}{$\mathrm{OC}$} \\
\hline & $\mathrm{N}$ & $\%$ & $\mathrm{~N}$ & $\%$ & $\mathrm{~N}$ & $\%$ & $\mathrm{~N}$ & $\%$ \\
\hline None & 11 & 11 & 1 & 4 & 14 & 15 & 2 & 9 \\
\hline 1 to 3 Courses & 31 & 33 & 11 & 50 & 31 & 33 & 10 & 45 \\
\hline 4 or more Courses & 45 & 48 & 10 & 45 & 42 & 45 & 10 & 45 \\
\hline \multirow[t]{3}{*}{ No Response } & 5 & 5 & 0 & 0 & 5 & 5 & 0 & 0 \\
\hline & - & 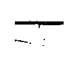 & $\longrightarrow$ & - & - & $\longrightarrow$ & - & $\longrightarrow$ \\
\hline & 92 & 97 & 22 & 99 & 92 & 98 & 22 & 99 \\
\hline
\end{tabular}

Since social science was the predominant major, there should have been exposure to: sociology and psychology. Forty-five per cent of the OC sample had completed four or more courses in psychology and/or sociology. The SWC sample had $48 \%$ completing four or more courses in psychology and 45\%, in sociology. It was noted in the OC sample that there we re some people who had no exposure to either psychology or sociology.

\section{Socio-Economic Background}

While $59 \%$ of the SWC sample's and $62 \%$ of the OC sample's fathers were "Professional persons" or Proprietor, managerial . . ., there were $22 \%$ of the SWC sample in "Skilled, Semi-skilled worke $r^{\prime \prime}$ classification as compared with $9 \%$ in the OC sample. Pins 
found slightly more than half below the "Professional" and

"Proprietor..." groups. (5)

TABLE 13

OCCUPATION OF FATHER

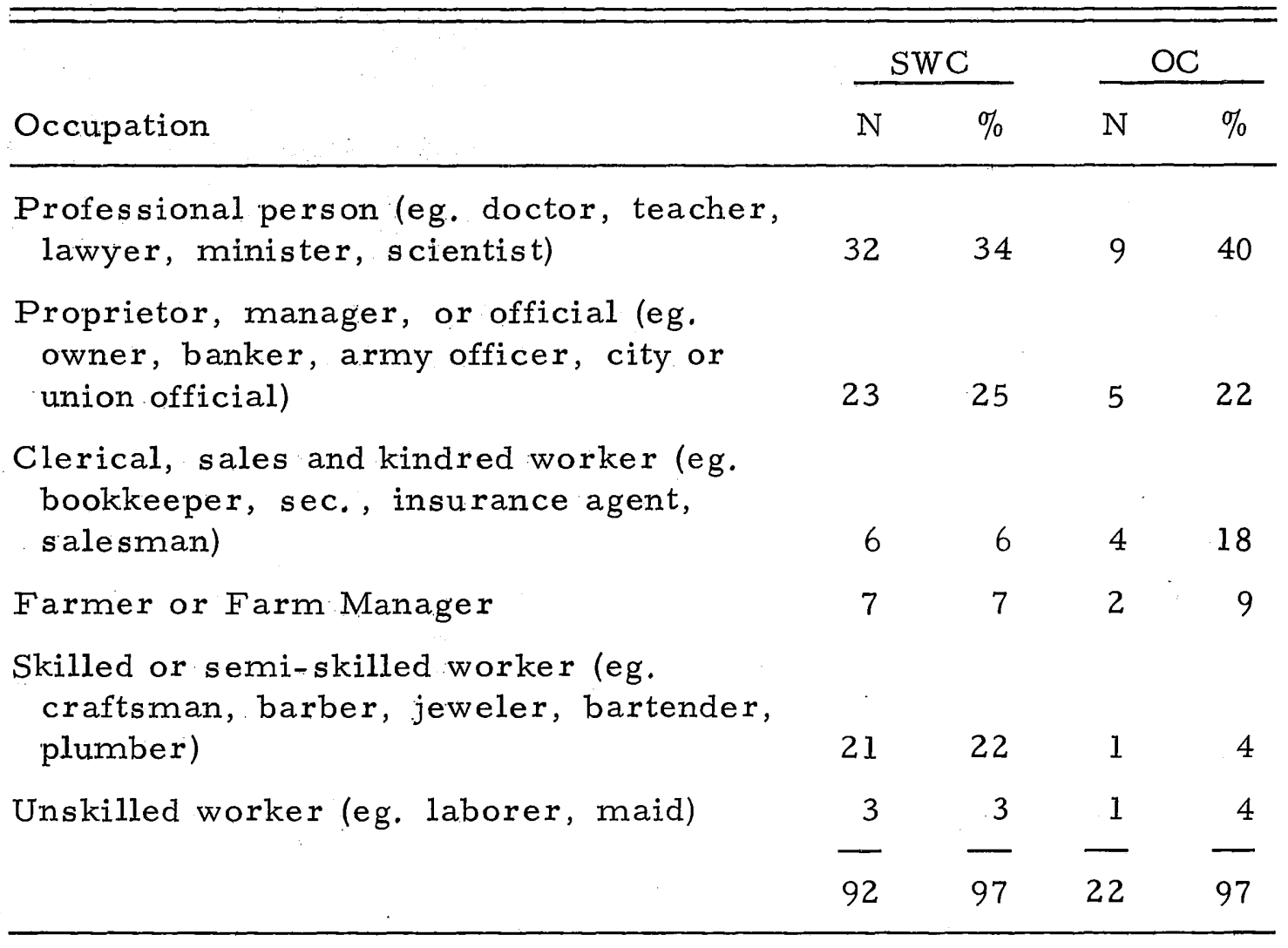

Relatives in Social Work

Thirty-six per cent of the OC sample and $13 \%$ of the SWC sample had relatives employed as social workers. The percentage in the OC sample was quite high compared to Pins', 13\%. These figures are low compared to students in medicine (50\%) and law (51\%) with family. members in the respective professions. (6) 
TABLE 14

EDUCATION OF PARENTS

\begin{tabular}{|c|c|c|c|c|c|c|c|c|}
\hline \multirow[b]{3}{*}{ Education } & \multicolumn{4}{|c|}{ SWC } & \multicolumn{4}{|c|}{$\mathrm{OC}$} \\
\hline & \multicolumn{2}{|c|}{ Father } & \multicolumn{2}{|c|}{ Mother } & \multicolumn{2}{|c|}{ Father } & \multicolumn{2}{|c|}{ Mother } \\
\hline & $\mathrm{N}$ & $\%$ & $\mathrm{~N}$ & $\%$ & $\mathrm{~N}$ & $\%$ & $\mathrm{~N}$ & $\%$ \\
\hline \multicolumn{9}{|l|}{ Never attended high } \\
\hline s chool & 18 & 19 & 6 & 6 & 1 & 4 & 2 & 9 \\
\hline Attended high s chool & 8 & 8 & 14 & 15 & 1 & 4 & 2 & 9 \\
\hline \multicolumn{9}{|l|}{ Completed high } \\
\hline school & 18 & 19 & 29 & 31 & 4 & 18 & 4 & 18 \\
\hline Attended college & 11 & 11 & 11 & 11 & 4 & 18 & 3 & 13 \\
\hline Completed college & 9 & 9 & 22 & 23 & 8 & 36 & 8 & 36 \\
\hline Did graduate work & 26 & 28 & 9 & 9 & 4 & 18 & 3 & 13 \\
\hline Do not know & 1 & 1 & 0 & 0 & & & & \\
\hline \multirow[t]{3}{*}{ No response } & 1 & 1 & 1 & 1 & & & & \\
\hline & - & 一 & - & - & - & - & - & - \\
\hline & 92 & 96 & 92 & 96 & 22 & 98 & 22 & 98 \\
\hline
\end{tabular}

A larger percentage of the OC sample's parents, over $50 \%$, and the SWC sample's parents, over $40 \%$, went beyond a high school education than did those in Pins' study. (7) In all three groups the fathers tended to have more education than the mothers.

\section{Experience in Community Activities and Social Work}

As social workers work with people and groups of people, it would be reas onable to expect participation in community and school organizations. A rough measure of the quality of their participation would be the extent of their leadership activity. Table 15 indicated that in both samples they were usually. somewhat active with about 
one-fourth being very active. Table 16 showed the degree of leadership activity with about one-third seldom holding leadership positions and a little over one-fourth frequency holding leadership positions.

TABLE 15

EXTENT OF ACTIVITY IN SCHOOL OR COMMUNITY ORGANIZATIONS

\begin{tabular}{lrrrrr}
\hline & \multicolumn{2}{c}{ SWC } & & \multicolumn{2}{c}{ OC } \\
\cline { 2 - 3 } \cline { 5 - 6 } Extent & $\mathrm{N}$ & & & $\mathrm{N}$ & $\%$ \\
\hline Not active at all & 13 & 14 & 1 & 4 \\
Somewhat active & 50 & 54 & 16 & 72 \\
Quite active & 27 & 29 & 5 & 22 \\
No response & 2 & 2 & 0 & 0 \\
& - & - & - & -22 & 98 \\
\hline
\end{tabular}

TABLE 16

LEADERSHIP ACTIVITY IN SCHOOL OR COMMUNITY ORGANIZATIONS

\begin{tabular}{lrrrrr}
\hline \hline & \multicolumn{2}{c}{ SWC } & & \multicolumn{2}{c}{ OC } \\
\cline { 2 - 3 } Extent & $\mathrm{N}$ & $\%$ & & $\mathrm{~N}$ & $\%$ \\
\hline Hardly ever & 30 & 32 & 8 & 36 \\
Occasionally & 30 & 32 & 8 & 36 \\
Frequently & 25 & 27 & & 6 & 27 \\
No response & 7 & 7 & & 0 & 0 \\
& -92 & -98 & & 22 & 99 \\
\hline
\end{tabular}


TABLE 17

SOCIAI WORK EXPERIENCE

\begin{tabular}{lllllr}
\hline \hline & \multicolumn{2}{c}{ SWC } & & \multicolumn{2}{c}{ OC } \\
\cline { 2 - 3 } \cline { 5 - 6 } Item & $\mathrm{N}$ & $\%$ & & $\mathrm{~N}$ & $\%$ \\
\hline Full time paid basis & 30 & 32 & & 7 & 31 \\
Paid employee during & & & & & \\
$\quad$ summer & 21 & 22 & & 8 & 36 \\
Part-time paid employee & 12 & 13 & & 2 & 9 \\
Volunteer & 45 & 48 & & 6 & 27 \\
\hline
\end{tabular}

Previous paid experience in social work or a closely related activity was found in $54 \%$ of the OC sample and $44 \%$ of the SWC sample. Volunteer experience was about as frequent in the SWC sample as paid experience but much less frequent in the OC sample. Many people in each sample had more than one type of paid experience. They often had both paid and volunteer experience.

\section{Timing of Vocational Development}

Awareness of social work as a career occurred in $62 \%$ of the OC sample after graduation from high school and in $18 \%$ after graduation from college. The most frequent time in both samples was during the first three years of college. It was noted that the SWC sample tended to become aware of social work as a career earlier than the OC sample, due in part to the youngest age bracket in SWC. 
TABLE 18

TIME OF AWARENESS OF SOCIAI WORK AS A CAREER

\begin{tabular}{|c|c|c|c|c|}
\hline \multirow[b]{2}{*}{ Time } & \multicolumn{2}{|c|}{ SWC } & \multicolumn{2}{|c|}{$\mathrm{OC}$} \\
\hline & $\mathrm{N}$ & $\%$ & $\mathrm{~N}$ & $\%$ \\
\hline Prior to last 3 years of high s chool & 10 & 10 & 3 & 13 \\
\hline During the last 3 years of high school & 25 & 27 & 4 & 18 \\
\hline During the first 3 years of college & 32 & 34 & 9 & 40 \\
\hline During the last year of college & 8 & 8 & 1 & 4 \\
\hline After graduation from college & 9 & 9 & 4 & 18 \\
\hline Other & 3 & 3 & & \\
\hline \multirow[t]{3}{*}{ Do not remember } & 5 & 5 & 1 & 4 \\
\hline & - & - & - & - \\
\hline & 92 & 96 & 22 & 96 \\
\hline
\end{tabular}

TAB LE 19

TIME FIRST CONSIDERED SOCIAL WORK AS A CAREER

\begin{tabular}{|c|c|c|c|c|}
\hline \multirow[b]{2}{*}{ Time } & \multicolumn{2}{|c|}{ SWC } & \multicolumn{2}{|c|}{$\mathrm{OC}$} \\
\hline & $\mathrm{N}$ & $\%$ & $\mathrm{~N}$ & $\%$ \\
\hline Prior to last 3 years of high school & 5 & 5 & 2 & 9 \\
\hline During the last 3 years of high school & 20 & 21 & 1 & 4 \\
\hline During first 3 years of college & 28 & 30 & 7 & 31 \\
\hline During the last year of college & 11 & 11 & 2 & 9 \\
\hline After graduation from college & 17 & 18 & 9 & 40 \\
\hline Do not remember & 0 & 0 & 1 & 4 \\
\hline \multirow[t]{3}{*}{ Other } & 11 & 11 & & \\
\hline & - & $\longrightarrow$ & - & - \\
\hline & 92 & 97 & 22 & 97 \\
\hline
\end{tabular}

Forty per cent of the OC sample first considered social work as a career during college and $40 \%$ after graduation. The SWC sample gave first consideration at an earlier time with $26 \%$ doing so 
during high school. The percentage of people first considering social work as a career at any. one time was similar in each sample with the exception of more of the SWC sample giving first consideration during the last three years of high school, and more of the OC sample after graduation from college.

TABLE 20

TIME OF CHOICE OF SOCIAL WORK AS A CAREER

\begin{tabular}{|c|c|c|c|c|}
\hline \multirow[b]{2}{*}{ Time } & \multicolumn{2}{|c|}{ SWC } & \multicolumn{2}{|c|}{$\mathrm{OC}$} \\
\hline & $\mathrm{N}$ & $\%$ & $\mathrm{~N}$ & $\%$ \\
\hline Prior to last 3 years of high school & 0 & 0 & 0 & 0 \\
\hline During last 3 years of high s chool & 9 & 9 & 1 & 4 \\
\hline During first 3 years of college & 19 & 20 & 3 & 13 \\
\hline During last year of college & 10 & 10 & 4 & 18 \\
\hline After graduation from college & 10 & 10 & 11 & 50 \\
\hline Do not remember & 1 & 1 & 0 & 0 \\
\hline Have not decided & 35 & 38 & 1 & 4 \\
\hline Other & 1 & 1 & & \\
\hline \multirow[t]{3}{*}{ No response } & 7 & 7 & 2 & 9 \\
\hline & - & - & - & $\longrightarrow$ \\
\hline & 92 & 96 & 22 & 98 \\
\hline
\end{tabular}

Studies have indicated that $53 \%$ to $70 \%$ of college students decide upon a vocation before entering college. (8) A little over $80 \%$ of the OC did not decide upon social work before entering college. Fifty per cent did not decide until after graduation from college. Only one-half of the SWC sample had decided upon social work as a career. Twenty-three per cent of the SWC sample were employed 
in some field of social work,

Factors Influencing Selection of Occupation

Table 21

SOURCES OF INFORMATION ABOUT SOCIAL WORK

\begin{tabular}{|c|c|c|c|c|}
\hline \multirow[b]{2}{*}{ Source } & \multicolumn{2}{|c|}{ SWC } & \multicolumn{2}{|c|}{$\mathrm{OC}$} \\
\hline & $\mathrm{N}$ & $\%$ & $\mathrm{~N}$ & $\%$ \\
\hline $\begin{array}{l}\text { Service received from social worker or } \\
\text { social work agency }\end{array}$ & 15 & 16 & 1 & 4 \\
\hline Direct work experience in social work & & & & \\
\hline or closely related activities & 49 & 53 & 12 & 54 \\
\hline College guidance department or staff & 22 & 23 & 4 & 18 \\
\hline College courses or instructors & 56 & 60 & 14 & 63 \\
\hline High school guidance program & 7 & 7 & 0 & 0 \\
\hline $\begin{array}{l}\text { Non-s chool connected vocational } \\
\text { guidance }\end{array}$ & 7 & 7 & 0 & 0 \\
\hline $\begin{array}{l}\text { Relative, friend or acquaintance who is } \\
\text { a social worker }\end{array}$ & 35 & 38 & 14 & 63 \\
\hline $\begin{array}{l}\text { Relative, friend or acquaintance who is } \\
\text { active in community welfare activities }\end{array}$ & 28 & 30 & 7 & 31 \\
\hline Fellow students in college & 19 & 20 & 5 & 22 \\
\hline $\begin{array}{l}\text { Movie, Radio, TV, books, newspapers } \\
\text { or magazines }\end{array}$ & 32 & 34 & 10 & 45 \\
\hline $\begin{array}{l}\text { Social work recruitment program, } \\
\text { speaker, or literature }\end{array}$ & 26 & 28 & 6 & 27 \\
\hline Other & 12 & 13 & 1 & 4 \\
\hline No Response & 1 & 1 & 0 & 0 \\
\hline
\end{tabular}

College courses or instructors were one of the major sources of information about social work. An equally important source in the OC sample was a relative, friend or acquaintance who was a social worker. Direct work experience in social work or closely related activities was important to over one-half of both samples. 
TABLE 22 INFLUENTIAL FACTORS IN CONSIDERING SOCIAL
WORK AS A CAREER

\begin{tabular}{|c|c|c|c|c|}
\hline \multirow[b]{2}{*}{ Item } & \multicolumn{2}{|c|}{ SWC } & \multicolumn{2}{|c|}{$\mathrm{OC}$} \\
\hline & $\mathrm{N}$ & $\%$ & $\mathrm{~N}$ & $\%$ \\
\hline $\begin{array}{l}\text { Parent, husband, or wife } \\
\text { Minister, priest, rabbi or other }\end{array}$ & 24 & 26 & 3 & 13 \\
\hline $\begin{array}{l}\text { religious leader } \\
\text { Participation in college and community }\end{array}$ & 7 & 7 & 2 & 9 \\
\hline organizations & 23 & 25 & 7 & 31 \\
\hline $\begin{array}{l}\text { Social Work recruitment program, } \\
\text { speaker or literature }\end{array}$ & 15 & 16 & 1 & 4 \\
\hline School or community guidance program & 11 & 11 & 1 & 4 \\
\hline $\begin{array}{l}\text { College courses or instructors } \\
\text { Undergraduate course in social work }\end{array}$ & 40 & 43 & 12 & 53 \\
\hline $\begin{array}{l}\text { or social welfare } \\
\text { Direct work or volunteer experiences } \\
\text { in social work or closely related }\end{array}$ & 21 & 22 & 7 & 31 \\
\hline activities & 66 & 71 & 13 & 59 \\
\hline $\begin{array}{l}\text { Service received from social worker or } \\
\text { social work agency }\end{array}$ & 7 & 7 & 1 & 4 \\
\hline $\begin{array}{l}\text { Relative, friend or acquaintance who } \\
\text { is a social worker }\end{array}$ & 12 & 13 & 12 & 54 \\
\hline $\begin{array}{l}\text { Relative, friend, or acquaintance who } \\
\text { is active in community and welfare } \\
\text { activities }\end{array}$ & 8 & 8 & 1 & 4 \\
\hline No response & 6 & 6 & 0 & 0 \\
\hline
\end{tabular}

Direct work experience was the most important factor influencing considering social work as a career. This was especially so in the SWC sample $(71 \%)$. Over $70 \%$ in Pins' study indicated it as having the greatest influence. (9) College courses or instructors was the next most important factor. It was equally an influential factor in the $O C$ sample as a relative, friend or acquaintance who was a social worker. 
TABLE 23

MAJOR REASONS FOR CONSIDERING SOCIAL WORK

\begin{tabular}{|c|c|c|c|c|}
\hline \multirow[b]{2}{*}{ Reason } & \multicolumn{2}{|c|}{ SWC } & \multicolumn{2}{|c|}{$\mathrm{OC}$} \\
\hline & $\mathrm{N}$ & $\%$ & $\mathrm{~N}$ & $\%$ \\
\hline $\begin{array}{l}\text { Social Work is an interesting and exciting } \\
\text { profession }\end{array}$ & 24 & 26 & 8 & 36 \\
\hline $\begin{array}{l}\text { Social Work will give me social status } \\
\text { and prestige }\end{array}$ & 0 & 0 & 0 & 0 \\
\hline $\begin{array}{l}\text { I think I can succeed in this kind of work } \\
\text { Social work makes an important contribu- }\end{array}$ & 20 & 21 & 3 & 13 \\
\hline tion to individuals and society & 50 & 54 & 11 & 50 \\
\hline $\begin{array}{l}\text { Salaries and working conditions are good } \\
\text { in social work }\end{array}$ & 4 & 4 & 0 & 0 \\
\hline I enjoy working with people & 60 & 64 & 11 & 50 \\
\hline $\begin{array}{l}\text { I was offered a job in social work } \\
\text { Social work can help me become a } \\
\text { better person, parent and marriage }\end{array}$ & 2 & 2 & 5 & 22 \\
\hline partner & 6 & 6 & 1 & 4 \\
\hline $\begin{array}{l}\text { Job opportunities and job security are } \\
\text { good in social work }\end{array}$ & 1 & 1 & 4 & 18 \\
\hline Other & 0 & 0 & 1 & 4 \\
\hline No response & 3 & 3 & 0 & 0 \\
\hline
\end{tabular}

The SWC sample and the OC sample indicated that enjoying working with people and social work making an important contribution to individuals and society. were the most important reasons for considering social work as a career. The SWC sample placed more importance on enjoying working with people. The OC sample gave equal importance to both reasons.

The enhancement of social functioning was of most importance to $58 \%$ of the SWC sample and $45 \%$ of the OC sample. The OC sample 
gave almost the same importance to helping people with problems.

The SWC sample placed much less importance $(20 \%)$ on helping people with problems.

TAB LE 24

MOST IMPORTANT FUNCTION OF SOCIAL WORK

\begin{tabular}{|c|c|c|c|c|}
\hline \multirow[b]{2}{*}{ Function } & \multicolumn{2}{|c|}{ SWC } & \multicolumn{2}{|c|}{$\mathrm{OC}$} \\
\hline & $\mathrm{N}$ & $\%$ & $\mathrm{~N}$ & $\%$ \\
\hline $\begin{array}{l}\text { Social work helps people with problems } \\
\text { Social work helps build a better com- } \\
\text { munity (locally, nationally, inter- } \\
\text { nationally) }\end{array}$ & 19 & 20 & 9 & 40 \\
\hline $\begin{array}{l}\text { Social work helps people become } \\
\text { happier, more creative and us eful }\end{array}$ & & & : & \\
\hline individuals & 54 & 58 & 10 & 45 \\
\hline No Response & 7 & 7 & 0 & 0 \\
\hline & 92 & 98 & 22 & 98 \\
\hline
\end{tabular}

TABLE 25

METHOD OF SOCIAL WORK CONCENTRATION

\begin{tabular}{lrrrrr}
\hline & \multicolumn{2}{c}{ SWC } & & \multicolumn{2}{c}{ OC } \\
\cline { 2 - 3 } \cline { 5 - 6 } Method & $\mathrm{N}$ & $\%$ & & $\mathrm{~N}$ & $\%$ \\
\hline Administration & 3 & 3 & & 0 & 0 \\
Casework & 31 & 33 & & 15 & 68 \\
Community organization & 5 & 5 & & 0 & 0 \\
Group work & 8 & 8 & & 2 & 9 \\
Research & 2 & 2 & & 1 & 4 \\
Not yet determined & 37 & 40 & & 4 & 18 \\
No response & 6 & 6 & & 0 & 0 \\
& - & & & - & -22 \\
\end{tabular}


In both samples, casework was the most frequently chosen method of concentration. Forty per cent of the SWC sample and $18 \%$ of the OC sample had not chosen a method. Some of the SWC sample who had not decided on social work as a career had decided on a method for concentration.

TABLE 26

OTHER CAREERS CONSIDERED OR TRIED

\begin{tabular}{lrrrrr}
\hline & \multicolumn{2}{c}{ SWC } & & \multicolumn{2}{c}{ OC } \\
\cline { 2 - 3 } \cline { 5 - 6 } Career & $\mathrm{N}$ & $\%$ & & $\mathrm{~N}$ & $\%$ \\
\hline Business & 18 & 19 & & 8 & 36 \\
Engineering & 1 & 1 & & 0 & 0 \\
Law & 2 & 2 & & 1 & 4 \\
Medicine & 0 & 0 & & 1 & 4 \\
Nursing & 8 & 8 & & 4 \\
Teaching & 28 & 30 & 7 & 31 \\
Other & 20 & 21 & & 9 \\
No Response & 15 & 16 & & 2 & 9 \\
& -12 & - & -27 & -97 \\
\hline
\end{tabular}

Over one-third of the OC sample and about one-fifth of the SWC sample considered or tried a business career. Teaching was the most frequent choice in the SWC sample and the next most frequent in the OC sample. Before considering social work as a career, at least $60 \%$ of the SWC sample and $79 \%$ of the OC sample considered or tried another career. 
TABLE 27

REASONS FOR NOT FOLLOWING OTHER CAREER

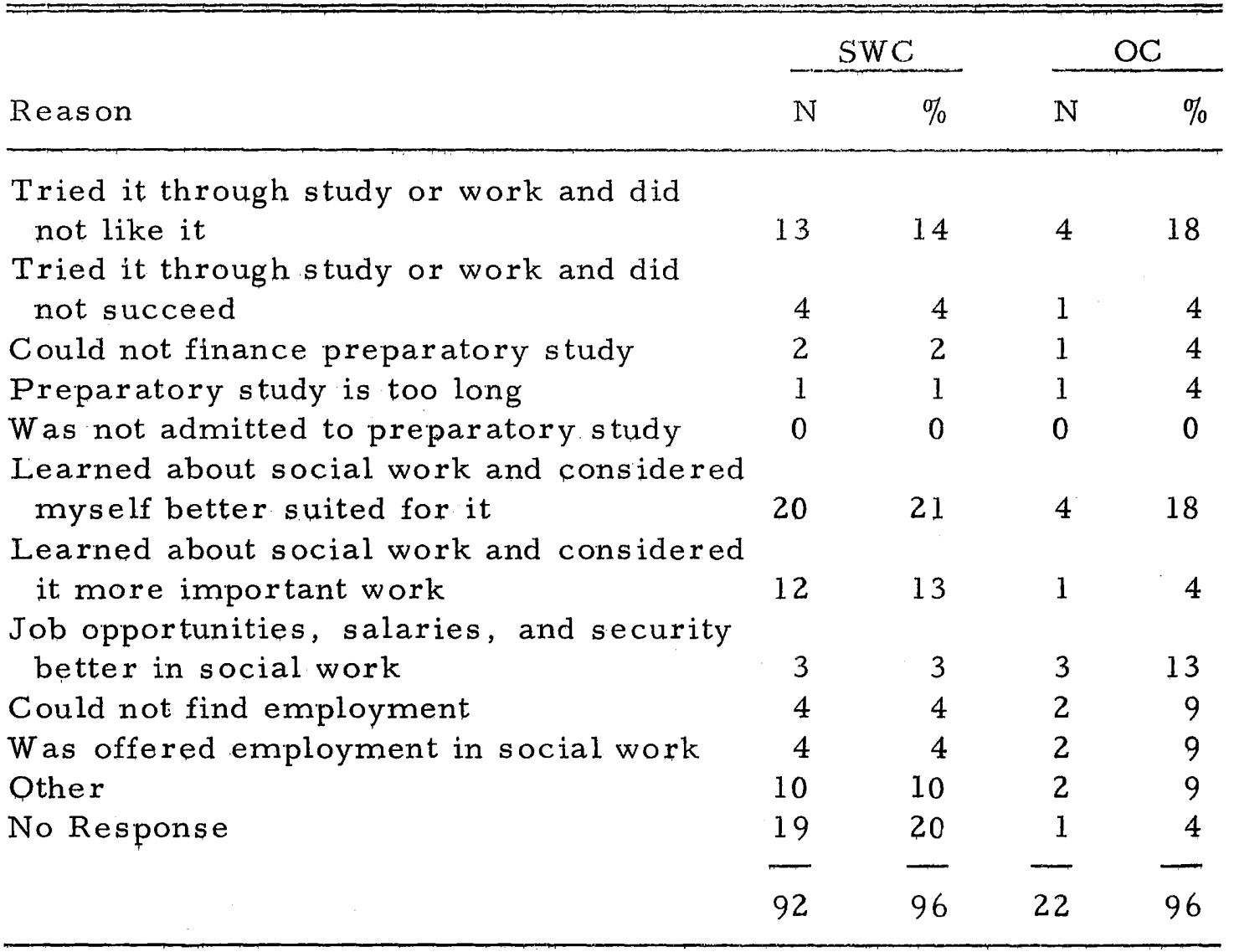

In the SWC sample the most frequent reason, $21 \%$, for not following the other career considered or tried was because they learned about social work and considered themselves better suited for it. The OC sample gave as its most frequent reasons learning about social work and considering themselves better suited for it and trying their other career through work or study and not liking it. "Othe $r$ " responses in the SWC sample included five who were still in the other career and three who were still considering it. 
TABLE 28

FACTORS INCREASING INTEREST IN SOCIAL WORK

\begin{tabular}{|c|c|c|c|c|c|c|c|c|}
\hline \multirow[b]{3}{*}{ Reason } & \multicolumn{4}{|c|}{ Little or None } & \multicolumn{4}{|c|}{ Moderate and Much } \\
\hline & \multicolumn{2}{|c|}{ SWC } & \multicolumn{2}{|c|}{$\mathrm{OC}$} & \multicolumn{2}{|c|}{ SWC } & \multicolumn{2}{|c|}{$\mathrm{OC}$} \\
\hline & $\mathrm{N}$ & $\%$ & $\mathrm{~N}$ & $\%$ & $\mathrm{~N}$ & $\%$ & $\mathrm{~N}$ & $\%$ \\
\hline \multicolumn{9}{|c|}{ Development of private } \\
\hline \multicolumn{9}{|c|}{$\begin{array}{l}\text { More prestige in the } \\
\text { designation of the pro- } \\
\text { fession than "social }\end{array}$} \\
\hline work" & 52 & 56 & 8 & .36 & 25 & 26 & 9 & 40 \\
\hline Legal Regulation & 48 & 52 & 15 & 68 & 24 & 25 & 2 & 9 \\
\hline More social action & 15 & 16 & 4 & 18 & 62 & 66 & 14 & 62 \\
\hline
\end{tabular}

Both the SWC and OC samples felt their interest in social work would have been most enhanced by higher salary scales and more social action. A greater emphasis was placed on more social action.

\section{Influence of Social Work Careers}

This section considers only the SWC sample, as the OC sample had no contact with Social Work Careers in Oregon, Incorporated.

Over one-half the sample had a positive reaction to their contact with SWC. This would indicate that most of the people were not discouraged by their contact. Included in "No Response" were people who indicated they did not remember contacting SWC. 
TAB LE 29

REACTION TO CONTACT WITH SWC

\begin{tabular}{lrr}
\hline \hline & \multicolumn{2}{c}{ SWC } \\
\cline { 2 - 3 } Reaction & $\mathrm{N}$ & $\%$ \\
\hline Very negative & 2 & 2 \\
Somewhat negative & 7 & 7 \\
Neither positive nor negative & 11 & 11 \\
Somewhat positive & 24 & 25 \\
Very positive & 38 & 41 \\
No response & 10 & 10 \\
& - & -92 \\
\hline
\end{tabular}

TABLE 30

ACTIONS SINCE FIRST CONTACT WITH SWC

\begin{tabular}{lrr}
\hline & \multicolumn{2}{c}{ SWC } \\
\cline { 2 - 3 } Actions & $\mathrm{N}$ & $\%$ \\
\hline Talked with others about social work & 49 & 53 \\
Read materials, such as pamphlets, on social work & 48 & 52 \\
Applied for paid employment in social work & 46 & 50 \\
Visited social agencies & 41 & 44 \\
Requested literature about social work & 30 & 32 \\
Took courses for better preparation for social work & 25 & 27 \\
Read books on social work & 25 & 27 \\
Requested college catalogs & 15 & 16 \\
Applied for volunteer work in a social agency & 14 & 15 \\
Applied for admission to a school of social work & 4 & 4 \\
Other & 5 & 5 \\
No Response & 13 & 14 \\
\hline
\end{tabular}


After their first contact with SWC, $50 \%$ or more of the people further explored the field of social work through reading or talking with other people or applied for paid employment in social work. This would be another indication that contacts with SWC were not dis couraging.

TABLE 31

FACTORS DISCOURAGING INTEREST AFTER CONTACT WITH SWC

\begin{tabular}{lcc}
\hline & \multicolumn{2}{c}{ SWC } \\
\cline { 2 - 3 } Factors & $\mathrm{N}$ & $\%$ \\
\hline Limited admission to school of social work & 17 & 18 \\
Length of time for education & 24 & 26 \\
Interest in another field & 24 & 26 \\
Pay scale & 14 & 15 \\
Adverse social agency experience & 18 & 19 \\
Contact with social worker & 10 & 10 \\
Influence of other people & 9 & 9 \\
Lack of job opportunities & & 9 \\
Other & 25 & 27 \\
No Response & 14 & 15 \\
\hline
\end{tabular}

${ }^{a}$ Not included in original questionnaire

There was a somewhat even distribution among the various factors discouraging interest. Those factors surrounding education for social work, contact with some aspect of social work and interest in another field were the most important. "Other" included three people who were still interested in social work, six who were 
discouraged because of factors relating to education (e.g., cost, academic requirements), eight who were discouraged because of personal or family factors (e. g. , time away from home, personal suitability) and four who felt social work was not "enough" or was not flexible.

\section{$\underline{\text { Summary }}$}

The SWC sample and the OC sample were predominately young people who had been raised in the Far West and were living in or near the Portland Metropolitan area. There was little representation of minority, racial, and religious groups in either sample. The majority of each sample was female. About one-half of the SWC sample and one-fifth of the OC sample were single. More than onehalf of the SWC sample had completed college, and many were attending college. All of the OC sample had completed college. Prior social work experience was common in both samples. Onehalf of the SWC sample, and all but one of the OC sample had chosen social work as a career. The majority of the SWC sample gave greater importance to enhancement of social functioning than to helping people with problems as a major function of social work. The OC sample gave equal importance to these two functions. Most of the SWC sample became aware of social work as a career during high school and decided on it as a career during college. The OC 
sample became aware of it during college and decided on it as a career after graduation from college. 


\section{Chapter Notes}

1. Arnulf M. Pins, Who Chooses Social Work, When and Why? Council on Social Work Education, New York, 1963.

2. Ibid., p. 30 .

3. Rex A, Skidmore and Milton G. Thackeray, "Male Social Workers--On the Increase, "Personnel Information, National As sociation of Social Workers, Vol, 6, No. 3, May 1963.

4. Pins, p. 38.

5. Ibid., p. 43 .

6. Ibid., p. 44 .

7. Ibid., p, 45 .

8. Anne Roe, The Psychology of Occupations, John'Wiley and Sons, New York, 1956, p. 264.

9. Pins, p. 77. 


\section{CHAPTER VI}

\section{SUMMARY AND ANALYTICAL FINDINGS}

This chapter includes an examination of the major descriptive findings and an analytical exploration of as sociation between selected factors.

Chi square was used to test the significance of these associations at the .05 level. When the size of the samples was such that over $20 \%$ of the expected frequencies were under five, associations were examined by ratios and percentages.

In the OC sample, the population $(\mathrm{N}=22)$ was selected at one point in time and is probably not a representative sample of all those entering Public Welfare in Oregon. Caution should be used in interpreting comparisons using the OC sample as one change in response can affect the percentages considerably.

\section{Descriptive and Analytical Findings}

The SWC and OC samples studied represented a young, upwardly mobile group from middle class homes who had lived most of their lives in the Far West. The samples were predominantely white and Protestant with little representation from minority racial and religious groups. Most attended college and majored in the social 
sciences, receiving above average grades in their last two years of school. They were somewhat active in school and community organizations and had previous social work experience.

A number of traits were selected by consensus with which to compare the Careers contacts (SWC), a group entering social service at the bachelor's level (OC), and the Pins' population who had entered graduate professional education. The purpose was to identify traits which would more likely be as sociated with entering the bachelor and professional levels in the field and to identify. productive motivational factors.

The null hypothesis was tested through the use of Chi square at the .05 level. When accepted, the groups could be considered as similar with respect to the traits compared. SWC could then be said to have made a contact with favorable prospects. Appendix II summarizes the se findings.

In the traits tested the SWC sample and the OC sample were similar except with respect to the time of decision to make social work a career. The similarities between the SWC sample and Pins' study: were in the areas of undergraduate majors, number of sociology courses completed, and the most important functions of social work. The OC sample and Pins' study were similar in all traits tested. The people who contacted SWC appeared to be good prospects for entry. into the field of social services at the bachelor's 
level; the OC sample, at the master's level.

In addition to the traits tested between the groups, the relationships between selected traits on the basis of total responses within a s ample were made. Significant differences were found between the occupation of fathers and the occupations of the SWC sample, between the education of the fathers and the education of both the SWC sample and the OC sample, and the time of awareness of social work as a career and the time of decision to make social work a career in both samples. Relationships between selected traits on the basis of individual responses were also made. A summary of the traits tested is found in Appendix III.

\section{Age, Sex, and Marital Status}

In the two samples the ratio of women to men was about $4: 1$. Seventy-six per cent of the SWC sample were under age thirty and $16 \%$, forty years or older. Fifty-three per cent of the OC sample were under thirty years and $22 \%$, forty years or older, with $13 \%$ over fifty years of age. The majority were or had been married, $52 \%$ in SWC and $81 \%$ in OC. The average number of children was one in SWC and two in OC. The marital status and number of children were related to the young age of both samples. 
Race and Religion

The racial composition of SWC was $96 \%$ white and $100 \%$ white in the OC sample. Six per cent of the SWC sample and $18 \%$ of the OC sample had no: religious identification. The percentage of Catholic and Jewish people in both samples was considerably. lower than in Pins' study. (1)

\section{Education}

Only $15 \%$ of the SWC sample had no college experience. Sixty per cent had completed four or more years of college, $29 \%$ were fulltime students, and $13 \%$ were part-time students. Fifty-four per cent of those with college experience majored in the social sciences. Almost half completed four or more courses in psychology and sociology. Sixty-two per cent had a grade average of "B" or better in the last two years of school.

All of the OC sample had graduated from college, and $59 \%$ majored in the social sciences. Almost half completed four or more courses in psychology and sociology. Less than $10 \%$ had completed no courses in psychology or sociology. Eighty-eight per cent reported a grade average of " $\mathrm{B}$ " or better in the last two years of school. The'largest percentage of people in both samples attended public universities: SWC $-26 \%$; OC $-40 \%$. 
In comparing the two samples and the Pins' study there was no significant difference in undergraduate majors. The size of the samples did not permit closer statistical analys is than the dichotomy of social sciences and other majors. There was no significant difference among the three populations in reference to the number of sociology courses completed. A significant difference was found between the SWC sample and the Pins' study in the number of psychology courses completed. The SWC sample had a greater percentage of people who had completed no courses in psychology.

\section{Socio-Economic Background}

Most people in the SWC and OC samples came from middle class homes as indicated by their fathers occupations. The fathers of $34 \%$ of the SWC sample and $40 \%$ of the OC sample were in the professions. The proprietor, manager, and official occupation group was $25 \%$ of the SWC sample and $22 \%$ in the OC sample. Six per cent of the SWC sample and $18 \%$ of the OC sample fathers were in the clerical, sales and kindred worker group. Twenty-two per cent of the SWC sample and $4 \%$ of the OC sample fathers were in the skilled or semi-skilled worker group. There was a significant difference between the SWC sample's current occupation and the occupation of the fathers.

The mothers of the SWC sample had less education than did the mothers of the OC sample. Fifty-two per cent and $36 \%$ respectively 
did not have any college education. The same tendency was noted in the fathers of both samples; forty-six per cent and $26 \%$ respectively. Thirty-seven per cent of the fathers and $32 \%$ of the mothers of the SWC sample completed college. Fifty-four per cent of the fathers and $49 \%$ of the mothers of the OC sample completed college. A larger percentage of the SWC sample's fathers, $28 \%$, than the fathers of the OC sample, $18 \%$, did graduate work. The fathers of both samples have more education than the fathers in Pins' study. (2) Statistically the SWC sample and the OC sample both had significantly more education than did the fathers of the samples' members.

Although both samples came from a fairly high socio-economic background, a bi-modal tendency appeared in the SWC sample in both education and occupation of fathers, with highs at each end of the scale. The OC sample peaked at the upper end of the scale.

The percentage of relatives employed as social workers in the two samples varied greatly, SWC-13\% OC-36\%. Three per cent of the fathers in the SWC sample were employed as social workers, and none of the fathers in the OC sample. Thirteen per cent of the mothers in the OC sample and $3 \%$ in the SWC sample had been employed in social work. 


\section{Work Experience}

The majority of those in the OC sample, $54 \%$, and $44 \%$ of the SWC s ample had had paid social work experience. Volunteer experience was more frequent in the SWC sample, $48 \%$ than in the OC sample, $27 \%$; however, this difference was not statistically significant. No significant relationship was found in the SWC sample with respect to prior social work experience and the decision to make social work a career.

\section{Choice of Social Work as a Career}

The SWC sample became aware of social work as a possible career earlier than did the OC sample. They also considered it at an earlier time than did the OC sample. Of the one-half of the SWC sample that had chosen social work as a career, they did so at an earlier time in their education than did those in the OC sample. In both samples the choice of social work as a career, predominately, was not made until after entering college. Fifty per cent of the OC sample did not decide until after graduation from college.

In both samples, $60 \%$ or more indicated that college courses or instructors were a major source of information about social work. Relatives, friends, or acquaintances who were social workers were of equal importance in the OC sample. The next most important 
source of information was direct work experience in social work or closely-related activities for over $53 \%$ of both samples.

In considering social work as a career, direct work or volunteer experience was important in both samples, SWC-71\%, OC $-59 \%$. College courses or instructors were the next most important, SWC $-43 \%, \mathrm{OC}-54 \%$. Again, relatives, friends, or acquaintances who were social workers were of equal importance with college courses or instructors in the OC sample.

Of those who have chosen a method of concentration in social work, casework was the most frequent choice by both samples. A significantly greater percentage of the SWC sample chose group work as a method of concentration than did those in the Pins' study.

As to motivation, the SWC sample indicated that enhancement of social functioning, $58 \%$, was more important than helping people with problems, $20 \%$. The OC sample was about equally divided between these two functions. Thirteen per cent of each sample were oriented towards building a better community. Along these same lines, interest in social work would have been increased by "more social action, " as indicated by over $60 \%$ of each sample. Over $50 \%$ indicated "higher salary scales" in social work would have increased interest.

The time of awareness, consideration, and decision in choosing social work as a career was not significantly, different between the OC 
sample and the Pins' study. There was a significant difference between the SWC sample and the Pins' study in these three areas. The SWC sample became aware, considered, and decided at an earlier time in reference to the educational process. The only significant difference between the SWC sample and the OC sample was in their time of decision to make social work a career. The tests of significance were made using the intervals during high school, during college, and after graduation from college. These categories were too broad to test the tendencies noted above.

In reasons for considering social work as a career, the SWC s ample and the Pins' study differed significantly. The SWC sample placed more importance on job security and opportunities and in thinking they could succeed in social work. The OC sample differed from the Pins' study: in giving more importance to being offered a job in social work.

\section{Contact With Social Work Careers}

None of the OC sample had had contact with Social Work Careers. Sixty-six per cent of the SWC sample had a positive reaction to their contact with SWC $41 \%$ very positive. After the first contact with SWC, over $50 \%$ sought to learn more about social work through reading and talking with others. Fifty per cent applied for paid employment in social work, and $15 \%$ sought volunteer work. The factor most 
discouraging interest in social work, as indicated by over one-fourth of the sample, was related to educational requirements for social work.

\section{$\underline{\text { Summary }}$}

Throughout the study it was noted that those people choosing social work as a career did so late in their education. Very few decided on social work as a career prior to entering college. College courses or instructors and direct social work experience were important influences in their consideration of social work as a career. A social science background was common, and the re was frequent exposure to psychology and sociology courses. Recruitment programs had little effect on their consideration of a social work career. Few people had close relatives employed as social workers.

The SWC sample included a number of people in college. Their similarity to the OC sample would indicate that they were good prospects for entering social services at the bachelor's level. Their difference from the Pins' study raised the question of the possibility of their entering into graduate education in social work or if the traits of graduate social work students had changed in recent years. The OC sample had the traits for being prospective graduate students in social work based on Pins! study.

It was not possible to determine if SWC was reaching people who were undecided about social work as a career or who had chosen 
social work as a career and were seeking as sistance in entering the field, At the time of the study about one-fourth of the SWC sample were already in the field, and about one-half of the sample had decided on a social work career. SWC was reaching a younger group than the OC sample and Pins' study.

Emphasis on providing more information about social work in basic psychology and sociology courses might provide more recruits with the potential for going into graduate school. Providing more opportunities for social work experience, especially voluntary, and an awareness of these opportunities prior to college could result in more people entering social services at various levels. 


\section{Chapter Notes}

1. Arnulf M. Pins, Who Chooses Social Work, When and Why? Council on Social Work Education, New York, 1963, p. 33.

2. Ibid., p. 66. 


\section{CONC LUSIONS}

The general purpose of this research study was to ascertain traits associated with the choice of social work as a career. The research was undertaken on the premise that the identification of these traits could lend significant information to the field of social work from the following vantage points:

1) For agencies in selecting social work personnel

2) For recruitment efforts such as SWC, enabling their focus to be as advantageous as possible

3) For schools of social work, at the graduate and undergraduate level, in furnishing information valuable to the process of evaluating potential students

4) For the contribution of knowledge in the field of social work about career patterns of non-professionals and professionals

A questionnaire adapted from one developed by Arnulf Pins was utilized for the data collection from two samples - SWC and OC. Two sets of general hypotheses were used to guide in exploration of the nature of the relationship of the observations, including comparisons of SWC and OC with Pins' findings. The two major hypotheses tested by means of inferential statistics were:

1) The traits of the Oregon sample (SWC and OC samples) are not significantly different from the 'Pins' sample. 
2): There is no significant difference between the OC and SWC samples with respect to independent variables influencing the time that a career in social work is chosen.

Through the use of a computer it was possible to compare numerous sets of traits by the Chi square test of significance. Other tendencies were discerned through utilization of descriptive statistics. The complexity of these as sociations has been related in Chapters V and VI, and it is difficult to make simple generalizations about them.

Both hypotheses-were rejected as a whole, but with important distinctions drawn. With regard to the first hypothesis, it was found that the SWC sample and Pins' sample were significantly different, but that the OC sample and Pins' sample we re not significantly different. Therefore, the people who contacted SWC appeared to be good prospects for entry into the field of social services at the bachelor's level, while people in the OC sample compared favorably with Pins' students at the graduate level.

Before accepting these conclusions, it is important that the limitations of the study be considered. In retrospect, it appeared that the questionnaire limited the scope of the study in several ways. Few questions were included that might have measured the values and personality traits of the sample. The pre-test, it was found, did not uncover all questions in which an alternate response was precluded, thus causing difficulty for some respondents in both samples. The utilization of some questionnaires was complicated 
by statistically ambiguous responses due to inadequately defined terminology.

Responses elicited on the questionnaire were the primary source of data for the study, and it was felt that personal, follow-up interviews would have increased the amount of information received and the degree of reliability of the responses, as well as the number of questionnaires completed and returned. Follow-up interviews could also have resolved some of the seeming inconsistencies in response on similar questions on the questionnaires.

In retrospect, it was felt that certain information on significant factors in background and career patterns had been neglected, and thereby the findings were limited. The omis sion of a lack-of-jobopportunities category in the consideration of factors that discouraged interest in social work was such a limitation. It was indicated by some that they learned of social work through employment or experience in social work or a closely related field. If this factor had been included, the project could have explored whether lack of sufficient education and lack of job opportunities we re directly correlated, with possible implications for recruitment in regard to volunteer experiences and employment.

Another limitation was the fact that primary emphasis in this study. was placed on those who had and had not decided against a career choice in social work, but not those who had made a definite 
decision against a career in social work. An examination of the reasons for their decisions would have had implications for the field. The relatively small size of the OC sample made for cautious consideration of the findings, since the reversal of one response in some instances could markedly affect the percentages. Time was of the es sence in the project; otherwise, it would have been helpful to have administered the questionnaire to a succession of two or three OC orientation groups. The SWC sample was limited to those people who had initiated a contact with SWC.' The individuals and groups who had been approached by SWC, but who had not made a subsequent response to the organization, were not studied. SWC is primarily accessible to people in the metropolitan area of Portland, Oregon, and therefore the population consisted primarily of urban residents to whom the program was more readily available; thus, rural areas were not proportionately represented. Since SWC had been in existence only two years prior to the study, the SWC sample was limited in terms of time differential.

It is important that the limited size of the population, representing only a small portion of those involved in social work or those considering social service as a career choice, be held in perspective. Generalizations about the social work community or those considering employment in the social work community should be cautiously drawn. 
The review of the literature on theories of career choice and the examination of source materials on recruitment in social work gave background and perspective to the research study. As the project proceeded, recognized relationships developed between the literature and the study's findings which seemed to confirm certain theoretical claims made by various authors.

Super (1) has said that the nature of a career pattern is determined by the individual's parental socio-economic level, mental ability, personality characteristics, and the opportunities to which he is exposed. This study examined parental socio-economic level and exposure to various opportunities and found the latter to be especially significant. Mental ability was indicated only superficially through grades received in school. The area of personality characteristics was definitely slighted in the questionnaire. Francel (2) confirmed the vital importance of personality characteristics to the social worker. This study might then have been enhanced by the added utilization of a personality inventory.

The findings seemed to indicate that contacts with social workers or employment opportunities in the field were significant to the choice of a social work career. This would appear to support Super's contention that such opportunities aid in "facilitating the process of maturation of abilities and interests" and aid "in reality testing and in the development of the self concept." (3) 
The possible role which such programs as the Peace Corps and VISTA might serve in channelling people into the fields of social welfare services should be studied. Such programs undoubtedly provide opportunities for service and reality testing at a key point in the individual's maturation level. Social work recruitment efforts should further utilize the identity-evolution process in young people, by providing the individual with the opportunity to play various roles. Local career programs have already discovered that college students having summer agency experiences are good recruitment prospects. The findings in this research study show that the visibility of social workers and social work employment opportunities are important influences on pos sible recruits to the field, and yet Kadushin's work (4) points to the low visibility of social workers to the general population. This would suggest that an important element in social work agencies and education is that of raising the level of visibility. of social workers for the general population.

Roe (5) stressed the matter of parental handling of children and its effect on vocational choice. The inclusion of items on the questionnaire which would have classified the respondent's handling by their parents would have indicated, from Roe's standpoint, whether the individual would have become person-directed or nonperson directed--an aspect of seeming significance to social work. Neibuhr (6) postulated in 1932 that the social worker probably 
finds in his vocation fulfillment of his hopes for a "mis sion to mankind." Present day social welfare consciousness, reinforced by the programs of Presidents Kennedy and Johnson, has provided more opportunities for individuals to try social welfare services at younger ages which would appear, from the findings of this research study, to be in the best interests of providing likely recruits for social work.

There are a number of questions and implications which may be drawn from this study in regard to recruitment efforts and further research.

The SWC sample and the OC sample represent individuals who have demonstrated a positive interest in social welfare services either through seeking information or through committing themselves to training. The question might well be raised as to whether the traits associated with this demonstrated interest are to be found in the general public. Are those traits which were isolated by this study unique to social work career aspirants? Would the administration of the questionnaire to a control group drawn from the general population or from those aspiring to careers in related fields be useful in validating the findings of this study? If like or similar traits were found to exist in one of the control groups suggested above, then the hypothesis that there is a vast, untapped reservoir for recruitment purposes would seem valid.

The historical development of the recruitment process has been 
traced and suggests implications which appear to be significant for both recruitment efforts and further research. Social work as a separate discipline was conceived in the early part of this century. Its birth was difficult and its development slow. In the early 1930's there were some two hundred full-time students in graduate schools of social work. In 1965, 2,748 were awarded Master's Degrees in Social Work. The role of the social worker has been profoundly affected by two world wars, a massive depression, rapid technological and scientific advances, and significant changes in cultural and social mores.

All of these factors have implications which relate to this study. Within the field, no clear distinctions have been drawn between the volunteer worker, the paid preprofessional worker, and the worker who does have a graduate degree. Is the public image of the social worker clouded by its inability to clearly recognize a social worker in the way that it would recognize a doctor? Is there a correlation between the small percentage of relatives in the field and the limited number of social work graduates a generation ago? Is the low visibility of the social worker related to these factors? Did the depression give a negative image of the social worker as one who "handed out the dole" which has persisted into the present? Could the later age of career choice among social workers in the OC sample be correlated with the fact that no undergraduate specialization is required in order to be 
hired as a public welfare caseworker? Does the fact that the OC sample was more interested in job security suggest selection through a bureaucratic system? Does the increasing number of social work career aspirants applying to graduate s chools reflect an impact on the public of the extensive social legislation passed under the Johnson Administration? Does it suggest heavy. subsidization through state and federal grants and stipends? Do VISTA and Peace Corps personnel possess like or similar traits to those is olated by this study, and if so do they offer a target for recruitment efforts?

In this study, the socio-economic level of career aspirants was measured on the basis of parental occupations. Perhaps adding aptitudes and attitudes as a dimension for further research would provide increased knowledge about traits associated with the choice of social work as a career.

The focus has been on traits associated with the choice of social work as a career, with lesser emphasis on the aptitudes of those who made the choice. A research project designed to assess aptitudinal factors in those who have demonstrated some degree of success in the field would perhaps be useful in enabling social work recruitment programs to focus more effectively on those individuals with the greatest potential for making social work an effective and satisfying career choice. In addition, an evaluation of degree of potential might be useful in channelling individuals into different levels and 
types of social work positions in which they would be able to function most effectively and this would in turn perhaps increase retention in the field.

In regard to attitudes, parental jobs, educational attainment, and income; categorization may provide a rough index of socioeconomic level but suggest little about the social attitudes which have probably, operated as a pervasive influence within the family structure. In both the OC and SWC samples the enhancement of social functioning and the desire to help others with problems were significant factors in determination of career choice. It would appear, then, that an attempt to explore the religious, ethical and humanistic values of social work career aspirants in greater depth would contribute to an increased knowledge of those personality factors which lead to an interest in social welfare services.

Another area which appears to have implications for further research is the low visibility of the social worker to young people who are involved in the process of making a career choice. Would recruitment efforts directed toward exposing elementary and high school youth to educational materials delineating the role of the social worker increase visibility? The findings in both the OC and SWC samples indicated that direct work experience in the field of volunteer services was a significant determinant in career choice. This would appear to have significance for future recruitment programs and study. 
Well planned and organized programs providing part-time or summer experiences in social welfare services would increase interest in social work as a career as well as increasing its visibility. As a corrolary, perhaps a thorough examination of the significance of various types of experience would enable recruitment to focus on those which appeared to yield greater awareness and interest on the part of participants.

Another question which might be raised regarding visibility in relation to recruitment is whether social work is even less visible to those who live in small communities and rural areas than it is to those in larger cities. Seventy-nine per cent of the SWC sample were living in cities with a population over 50,000. The National Social Work Careers organization reports that over 75 per cent of all inquiries come from urban centers. These figures suggest that recruitment efforts directed away from large metropolitan areas might be fruitful.

Colleges, too, offer an area for further study. Both the OC and the SWC samples indicated that fewer college students chose social work as a career during the undergraduate years than did college students who selected other careers. Few undergraduate educational institutions offer social work as a major field of study. The inference that this reduces the visibility of social work as a career choice on the undergraduate level could be tested by research 
methods. The implications of such a study for recruitment and for the social work profession as a whole appear to be significant. The possibilities of clarifying the roles and functions of the social worker and of introducing social work sequences into the curricula at this level would perhaps enhance both visibility and interest.

The fact that 60 per cent of the SWC sample and 63 per cent of the OC sample indicated that college courses or instructors were important factors in influencing their selection of social work as a career suggests several implications for further research. Which courses exerted this influence and what were the personality traits and knowledge of and orientation toward the social work field which caused particular instructors to exert such an influence? Another testable hypothesis might be that social work aspirants are dropouts from the fields of sociology and psychology (this hypothesis being based on the fact that 45 per cent of the OC sample had completed four or more courses in psychology and/or sociology and 48 per cent of the SWC sample had completed four or more courses in psychology and 45 per cent in sociology). Do the graduate schools of social work, in selecting students with qualifications which fit their criteria, screen out many applicants who might possess considerable potential to function on the professional level?

In addition to determining some traits associated with social work as a career choice, the project group has designated directions 
for recruitment efforts and further research which would benefit the field of social welfare. In view of present and projected manpower needs in the field, this would appear to be a needed contribution. 


\section{Chapter Notes}

1. Donald E. Super et al. , Vocational Development: A Framework for Research (New York: Columbia University Teachers Bureau of Publications, 1957), pp. 14-15.

2. Edward Francel, "Factors Associated with the Successful Outcome of Professional Training for Social Work, " unpublished $P h . D$, dissertation, cited in Manpower in Social Welfare: Research Perspectives, ed. by Edward Schwarta (New York: National Association of Social Workers, 1966), p. 87.

3. Super, op. cit.

4. Alfred Kadushin, "Determinants of Career Choice and Their Implications for Social Work, "Social Work Education, VI (No. 2, 1958), p. 19.

5. Anne Roe, "Early Determinants of Vocational Choice, "in Vocational Development and Career Development, ed. by Herman J. Peters and James C. Hansen (New York: The Macmillan Company, 1966), pp. 110-118.

6. Reinhold Niebuhr, The Contribution of Religion to Social Work (New York: Columbia University Press, 1932), p. 61. 


\section{A SELECTED BIBLIOGRAPHY}

\section{Books}

Arkin, Herbert, and Colton, Raymond R. Tables for Statisticians.

2d. ed. New York: Barnes and Noble, 1963.

Baer, Max Frand, and Roeber, Edward C. Occupational Information: The Dynamics of its Nature and Use. Chicago: Science Research Associates, Inc., 1964.

Bisno, Herbert. The Place of the Undergraduate Curriculum in Social Work Education. The Social Work Curriculum Study, Vo1. II. New York: Council on Social Work Education, 1959.

Brown, Esther Lucile. Social Work as a Profession. New York: Russell Sage Foundation, 1942.

Cohen, Nathan Edward. Social Work in the American Tradition. New York: The Dryden Press, 1958.

Davis, James A. Undergraduate Career Decisions. Chicago: Aldine Publishing Company, 1965.

Encyclopedia of Social Work, 15 th Is sue, New York: National As sociation of Social Workers, 1965.

Ginzberg, Eli et al. Occupational Choice, an Approach to a General Theory. New York: Columbia University, Press, 1951.

Hoppock, Robert. Occupational Information: Where to Get it and How to Use it in Counseling and Teaching. New York: McGraw-Hill, 1957.

Kutzik, Alfred J. Social Work and Jewish Values. Washington, D. C.: Public Affairs Press, 1959.

Maslow, A. H. Motivation and Personality. New York: Harper and Brothers, 1954. 
Merle, Sherman. A Summary Report of Undergraduate Social Welfare Education in the United States: A Survey of Programs, Students, and Faculty. New York: Council on Social Work Education, 1966.

Niebuhr, Reinhold. The Contributions of Religion to Social Work. New York: Columbia University Press, 1932.

Peters, Herman J. and Hansen, James C. (eds.), Vocational Development and Career Development. New York; The Macmillan Company, 1966.

Pins, Arnulf M. Who Chooses Social Work: When and Why? New York: Council on Social Work Education, 1963.

Roe, Anne. The Psychology of Occupations. New York: John Wiley and Sons, Inc. , 1956.

Rosenberg, Morris. Occupations and Values. Glencoe, Ill. : Free Press, 1957.

Shartle, Carroll I. Occupational Information. Englewood Cliffs, N. J.: Prentice-Hall, Inc., 1959.

Schwartz, Edward E. (ed.) Manpower in Social Welfare: Research Perspectives. New York: National Association of Social Workers, 1966.

Super, Donald. The Dynamics of Vocational Adjustment. New York: Harper and Brothers, 1942 .

. The Psychology of Adjustment. New York:

Harper and Brothers, 1942 .

- Vocational Development: A Framework for

Research. New York: Columbia University Teachers Bureau of Publications, 1957.

- The Vocational Maturity of Ninth Grade Boys.

New York; Columbia University Teachers Bureau of Publications, 1960.

Tagerson, Carroll T. The Relationship of Self Perception to Realism of Vocational Choice. Washington, D. C.: Catholic University of America Press, 1960. 
Wilensky, Harold L. Industrial Society and Social Welfare. New York: The Free Press, 1965.

\section{Articles in Journals or Magazines}

Annual Review. New York: National Commission on Social Work Careers, March, 1964; 1966; 1967.

Blau, Peter M. et al. "Occupational Choice: a Conceptual Framework, "Industrial Labor Relations Review, IX (July, 1956), 533-37.

Holland, John I. "A Theory of Vocational Choice," Journal of Counseling Psychology (Spring, 1959), 35-44.

Kadushin, Alfred. "Determinants of Career Choice and Their Implications for Social Work, "Social Work Education, VI (no. 2, 1958), $17-26$.

Kanter, David. "Social Work Recruitment and the Public Image," Social Work Education, VII (no. 1, 1959), 8-9 and 18-21.

Kidneigh, John C. and Lundberg, Horace W. "Are Social Work Students Different?" Social Work, III (July, 1958), 57-61.

McCornack, R. and Kidneigh, J. C. "The Vocational Interest Patterns of Social Workers, "Social Work Journal (October, 1954), $161-63$.

Pins, Arnulf M. "Development of Social Work Recruitment: A Historical Review, "The Social Service Review, XXXIX (March, 1965), 53-63.

"Recruit Whom for What?" NASW News. New York: National Association of Social Workers, November, 1967.

Samler, Joseph, "Psycho-Social Aspects of Work: A Critique of Occupational Information," Personnel and Guidance Journal (February, 1961), 458-65.

Underhill, Ralph. "Values and Post College Career Change," American Journal of Sociology, LXXII (September, 1966), 163 72 . 
Wittman, M. "The Implications of Social Welfare Needs in 1975 for Professional Education and Planning, "Social Service Review, XXXIX (Dec. , 1965), 459-67.

\section{Reports-Published}

Barker, Robert L., and Briggs, Thomas L. "Trends in the Utilization of Social Work Personnel: An Evaluative Research of the Literature." Research Report Number Two, Utilization of Social Work Personnel in Mental Hospitals Project. New York: National Association of Social Workers, June, 1966. (Processed).

U. S. Department of Health, Education, and Welfare. Closing the Gap - in Social Work Manpower. Washington, D. C.: U. S. Government Printing Office, November, 1965.

\section{Public Documents}

Oregon Public Welfare Commission, Salem, Oregon. Educational Leave Program Results. April 19, 1963. (Processed)

State of Oregon. Report of Public Welfare in Oregon for the Fiscal Year: July 1, 1944-June 30, 1945.

U. S. Public Law 90-248, HR 12080.90th Congress, December, 1967.

\section{Unpublished Materials}

Admittance Records. Portland State College, School of Social Work Files, 1967.

"The Certificate Program in the Social Services." Progress Report; A Section 1115 Project sponsored by the Oregon State Public Welfare Commission, The School of Social Work, Portland State College, in cooperation with the Division of Continuing Education, State System of Higher Education. Portland, Oregon, October, 1967. 
Guyler, Cathryn S. National Social Welfare Assembly. Minutes of Special Meeting on Recruitment, December 9, 1965.

"Helping Services: The Survey of Courses in Undergraduate Education." From the files of Dr. D. Jennings, Portland State College, School of Social Work, 1967.

"In Preparation for the Workshop on Careers in Social Work." NASW Newsletter, November, 1964.

Nicholls, Barbara. "Establishment of the School of Social Work." Preliminary Draft. Portland State College, School of Social Work, August, 1962.

Oregon Chapter of National Association of Social Workers, 1956-57 files obtained from Allen Hatch, Chapter Chairman.

"Proposal for a Program Leading to a Certificate in Social Service." Portland State College, School of Social Work. Revised: October 9, 1967.

Report of FSAA Personnel Committee. "Salary Policies and Ranges for Professional Positions: A Guide to FSAA Member Agencies." Approved by the Board of Directors, April 30, 1965; May, 1967.

\section{Interviews}

Catlin, Helen. Former director Central Volunteer Bureau, Portland, Oregon. December 4, 1967.

Cunneen, James, Former recruiter with the State Public Welfare Commission. November 11, 1967.

Selling, Carolyn. Executive Director, Social Work Careers in Oregon, Incorporated. November, 1967. 


\section{APPENDIX I}

\section{Instructions}

This is an independent scientific survey of careers in social work. Your careful, complete and honest answers to this questionnaire will help the field of social work to learn much about when, how.and why individuals decide to become social workers. In filling out this questionnaire, please bear the following in mind:

1. The questionnaire is not a test. There is no "grade" or other mark. The only "right" answer to the questions are those which best explain your situation or express your views.

2. All your responses will be confidential. Information will be reported only in the form of statistical summaries.

3. Answer every question in accordance with the directions. Please note that some questions ask you to check "all" those items which apply, while for some you are asked to check only the "two" or "three" most important items. Please read every question or statement carefully before answering.

4. Please place a check $(\sqrt{ })$ in the space provided for responses. It will not take you long to fill out this questionnaire. Please fill out the questionnaire and return in the enclosed self-addressed, stamped envelope.

5. Since this questionnaire is based on a national study, some items will not fit your particular situation. Please draw a line across any such questions and go on.

6. Please make any additional comments and suggestions you feel might be helpful on the back of the questionnaire.

Your participation is essential to the success of this study. Thank you for your cooperation.

NAME

Age as of October 1, 1967

Present Occupation

A. Are you a student this academic year? Full time Part Time

B. What is the highest grade you have completed?

High School $1 \frac{2}{2}-3 \frac{3}{3}{ }^{3}-\frac{4}{5} \quad 6 \quad$ or more
College 1


10. Relative, friend or acquaintance who is social worker

11. Relative, friend or acquaintance who is active in community and welfare activities.

H. Is, or was, a member of your family employed as a social worker?

Yes No

If YES, please check relationship below:

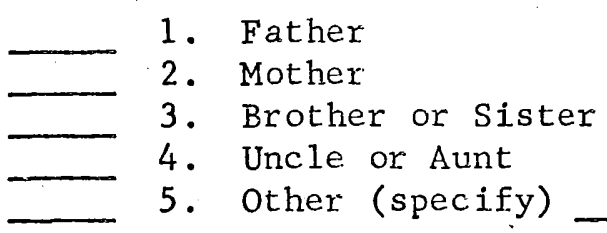

I. Did you ever have any direct work experience in social work or closely related activities.... Yes No

If your answer is NO, please skip to question "M"

If your answer is YES, please continue with questions $H, I, J, K$ and $L$

J. Have you ever worked in social work on a full-time paid basis for at least 6 months? . . . . Yes No

If YES, please check kind of agency:

1. Group Service (Y's, Scouts, Community Centers, Settlements)

2. Public Assistance (Department of Welfare)

3. Hospital or medical clinic

4. Psychiatric agency, clinic or institution (include mental hea1th)

5. Child and family welfare

6. Community planning (Community Chest, federation or welfare fund)

7. Other (specify)

$\mathrm{K}$. Have you ever worked in social work as a temporary paid employee during the summer months? . . . . Y Yes No

If YES, please check kind of agency:

1. Group Service (Y's, Scouts, Community Centers, Settlements)

2. Public Assistance (Department of Welfare)

3. Hospital or medical clinic

4. Psychiatric agency, clinic or institution (include mental health)

5. Child and family welfare

6. Community planning (Community Chest, federation or welfare fund)

7. Other (specify) 
L. Have you ever worked in social work as a part-time paid employee?

Yes. No

If YES, please check kind of agency:

1. Group Service

2. Public Assistance

3. Hospital or medical clinic

4. Psychiatric agency, clinic or institution

5. Child and family welfare

- 6. Community planning

7. Other (specify)

M. Have you ever served as a volunteer in a social work agency?

Yes No

If YES, please check kind of agency:

1. Group Service

- 2. Pub1ic Assistance

- 3. Hospital or medical clinic

- 5. Child and family welfare

6. Community planning

7. Other (specify)

N. In your work were you supervised by a graduate of a school of social work?

1. Yes

2. No

3. Do not know

0 . When did you first become aware of social work as a career?

(check only one)

1. Prior to the last three years of high school

2. During the last three years of high school

3. During the first three years of college

4. During the last year of college

5. After graduation from college

6. Do not remember

P. When did you first consider social work as a possible career for you? (Check only one)

1. Prior to the last three years of high school
2. During the last three years of high school
3. During the first three years of college
4. During the last year of college
5. After graduation from college
6. Do not remember 
Q. When did you definitely decide on social work as your career?

(Check only one)

1. Prior to the last three years of high school

- 2. During the last three years of high school

- 3. During the first three years of college.

4. During the last year of college.

- 5. After graduation from college

- 6. Do not remember

R. Before your first contact with "Social Work Careers", did you ever consider or try another career? . . . . Yes No

If your answer is NO, skip to question "U"

If your answer is YES, please continue with questions "S" and " $\mathrm{T}$ "

S. What other career did you consider or try? (Check only one. If there were more than one career, check only the most recent.)

1. Business

2. Engineering

3. Law

4. Medicine

5. Nursing

6. Teaching

7. Other (specify)

T. What is the one major reason why you did not follow the career you considered or tried? (Check only one)

1. Tried it through study or work and did not like it

2. Tried it through study or work and did not succeed

3. Could not finance preparatory study

4. Preparatory study is too long

5. Was not admitted to preparatory study

6. Learned about social work and considered myself better suited for it

7. Learned about social work and considered it more important work

8. Job opportunities, salaries and security better in social work

9. Could not find employment

10. Was offered employment in social work

11. Other (specify)

U. Which two of the following statements come closest to expressing the major reasons. why you have considered social work as your career?

(Check only two)

1. Social work is an interesting and exciting profession

2. Social work will give me social status and prestige

3. I think I can succeed in this kind of work 
4. Social work makes an important contribution to individuals and society

5. Salaries and working conditions are good in social work

6. I enjoy working wi.th people

7. I was offered a job in social work

8. Social work can help me become a better person, parent and marriage partner

9. Job opportunities and job security are good in social work 10. Other (specify)

V. Which one of the following three statements best expresses the func tion of social work which is most important to you? (Check only one)

1. Social work helps people with problems

2. Social work helps build a better community (locally, nationa1ly and internationally)

3. Social work helps people become happier, more creative and useful individuals

W. How do people close to you feel about your consideration of social work as a career? (Check one item for each person or group)
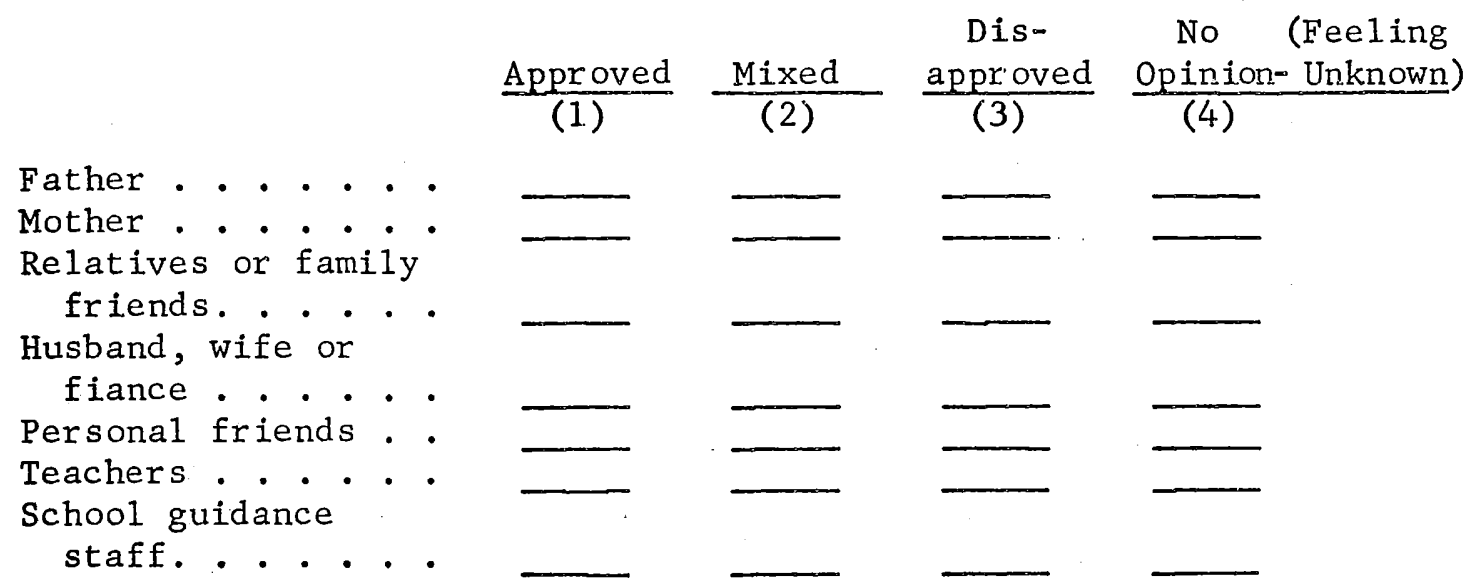

$\mathrm{x}$. In what method of social work would you concentrate? (Check one)

\section{Administration}

2. Casework

3. Community organization

4. Group work
5. Research

6. Not yet determined

Y. When did you make your choice of a social work method for concentration? (Check one)

1. Before $I$ thought in general terms about social work as my profession

2. At the same time that I decided on social work as my career

3. After I decided about social work but before I applied to a graduate school 
4. At the time I filled out the written application for graduate school but before my interview

5. During or after my interview but before admission

6. After official admission

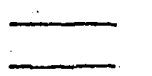

7. I have not yet chosen a method for concentration

Z. Age as of October 1, 1967:

$\begin{array}{ll}1 . & \text { Under } 15 \\ 2 . & 15 \text { to } 19 \text { years } \\ 3 . & 20 \text { to } 24 \text { years } \\ 4 . & 25 \text { to } 29 \text { years } \\ 5 . & 30 \text { to } 34 \text { years } \\ -6 . & 35 \text { to } 39 \text { years } \\ 7 . & 40 \text { to } 44 \text { years } \\ \text { 8. } & 45 \text { to } 49 \text { years } \\ 9 . & 50 \text { years or older }\end{array}$

AA. Sex ............ Male Female

BB. Current marital status (Check one)

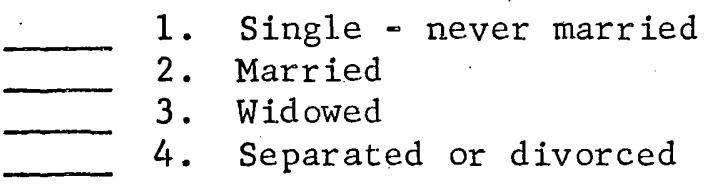

CC. Number of children under 21 years of age

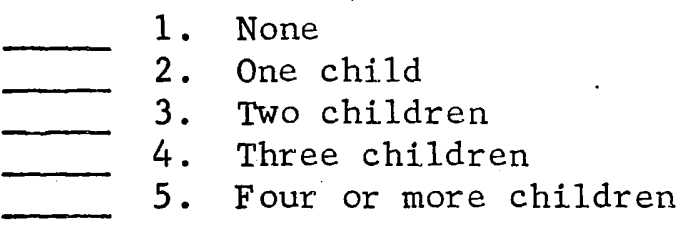

DD. Religious identification

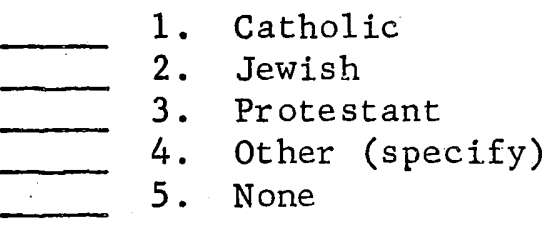

EE. Race

$$
\begin{aligned}
& \text { 1. Negro } \\
& \text { 2. White } \\
& \text { 3. Other (specify) }
\end{aligned}
$$

FF. What is, or was, the occupation of your father? (Check one)

1. Professional person (e.g., doctor, teacher, lawyer, minister, scientist)

2. Proprietor, manager or official (e.g., owner, banker, army officer, city or union official) 
3. Clerical, sales and kindred worker (e.g., bookkeeper, secretary, insurance agent, salesman)

4. Farmer or farm manager

5. Skilled or semi-skilled worker (e.g., craftsman, barber, jeweler, bartender, plumber)

6. Unskilled worker (e.g., laborer, maid)

GG. What is the current approximate income of both your parents?

(Check one)

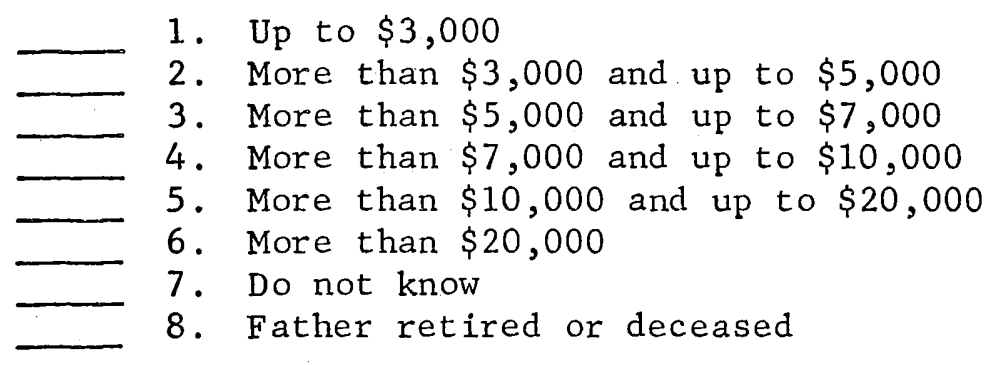

HH. What is the highest level of education achieved by your parents? (Check one item for father and one item for mother)

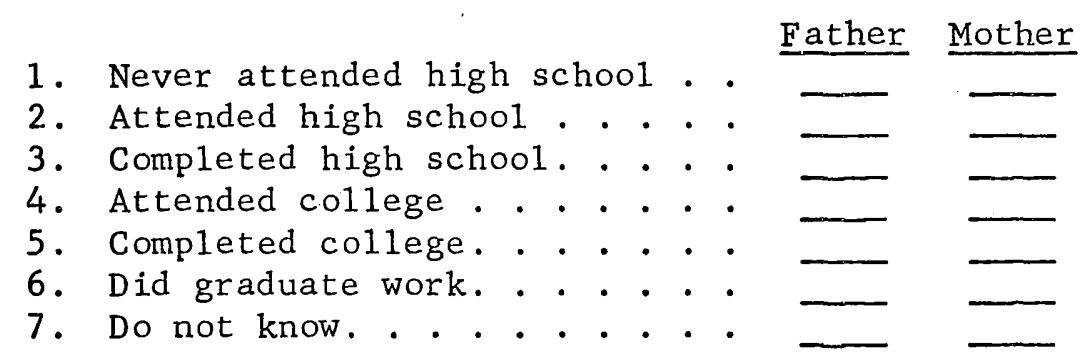

II. Was either your father or mother born outside the United States or Canada?

Yes

No

JJ. In what part of the country have you lived most of your life? (Check one)

1. New England (Maine, N.H., Mass., R.I., Conn., Vermont)

2. Middle Atlantic (N.Y., N.J., Pa., Delaware, Md., W.Va., District of Columbia)

3. Southeast (Va., N.C., S.C., Ga., Fla., Ky., Tenn., Ala., Miss., Ark., La.)

4. Southwest (Okla., Tenn., New Mexico, Arizona)

5. Central (Ohio, Ind., I11., Mich., Wisc., Minn., Iowa, Mo.)

6. Northwest (N.D., S.D., Neb., Kan., Mont., Idaho, Wyoming, Colorado, Utah)

7. Far West (Washington, Oreg., Nev., Calif., Hawaii, Alaska)

8. Canada

9. Country other than U.S. or Canada 
KK. In what size community did you live most of your life?

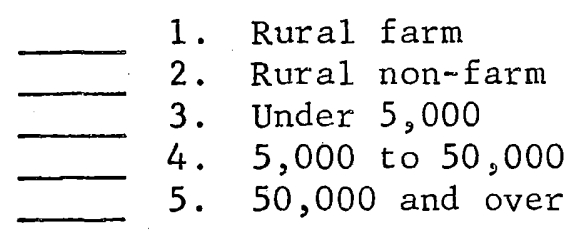

Present residence

$$
\begin{aligned}
& \begin{array}{ll}
\text { 1. Rural farm } \\
\text { 2. }
\end{array} \\
& \text { - 3. Under 5,000 } \\
& \text { - 4. } 5,000 \text { to } 50,000 \\
& \text { 5. 50,000 and over }
\end{aligned}
$$

Where 1 ived when contacted by Social Work Careers

$$
\begin{aligned}
& \begin{array}{ll}
\text { 1. Rural farm } \\
\text { 2. Rural non-farm }
\end{array} \\
& \text { - 3. Under } 5,000 \\
& \text { — 4. 5,000 to } 50,000 \\
& \text { 5. 50,000 and over }
\end{aligned}
$$

LL. From what kind of educational institution did you receive your undergraduate degree? (Check one)

1. Private liberal arts college not part of university

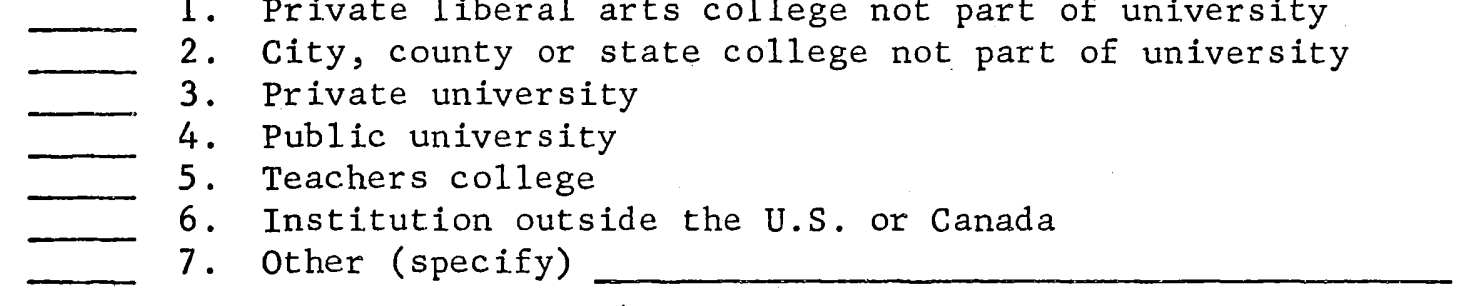

MM. If appropriate:

What was name and location of educational institution from which you received your undergraduate degree? (Please write in)

Name

City -State (or country

if not U.S. or Canada)

NN. If appropriate:

What was your approximate grade average in the last two years of school? (Check one)

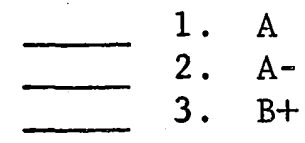

$$
\begin{array}{ll}
\text { 4. } & \text { B } \\
5 . & \text { B- } \\
\text { 6. } & \text { Ct } \\
\text { 7. } & \text { C or lower }
\end{array}
$$


00. What is (was) your "major" in your undergraduate work? (Check one)

1. Social Science (e.g., psychology, sociology, anthropology, history, economics)

2. Social work or social welfare

3. Physical Science (e.g., physics, chemistry)

4. Biological Science (e.g., zoology, biology)

5. English and Literature

6. Foreign Languages

7. Mathematics

8. Fine Arts

9. Education

10. Business

11. Other (specify)

12. Did not major

PP. How many undergraduate courses in psychology have you completed?

(Check one)

1. None

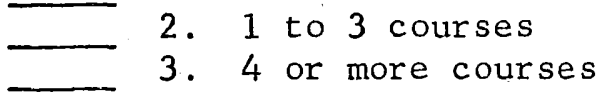

QQ. How many undergraduate courses in sociology have you completed?

(Check one)

1. None

2. 1 to 3 courses

3. 4 or more courses

RR. Do you now hold a degree in some field other than social work? Yes No If so, what kind?

SS. How active were you or are you, in organizations in either school or the community? (Check one)

1. Not active at all

2. Somewhat active

3. Quite active

TT. How often have you held leadership positions in these organizations? (Check one)

1. Hardly ever

2. Occasionally

3. Frequent1y

UU. Outside of financial aid (from a school, agency, foundation, etc., how would you finance your professional education? (Check all those which apply)

1. Earnings of husband or wife

2. Support from parents or relatives

3. Personal savings 
4. Borrowed funds

$\longrightarrow$ 5. G I Bil1

6. Part-time job in social work

7. Part-time job outside of social work

8. Other (specify)

VV. Did you receive financial aid for the academic year 1966-67?

Yes No

WW. Without financial aid, what would your arrangements be the first year of graduate school? (Check one)

1. I would manage without financial difficulty

- 2. I would manage but with some financial difficulty

- 3. I could undertake graduate education only with extreme financial hardship, but would manage somehow

4. I would be unable to undertake graduate education because of inability to finance it

5. Does not apply

6. Other

XX. What was your reaction to your contact with Social Work Careers? (Check one)

$\begin{array}{ll}\text { 1. } & \text { Very negative } \\ \text { 2. } & \text { Somewhat negative } \\ \text { 3. Neither positive nor negative } \\ \text { 4. Somewhat positive } \\ \text { 5. }\end{array}$

YY. Please check all forms of contact you have had with Social Work Careers. Underline the three most helpful.

1. Talk to groups

2. Private talks

3. Literature

4. Suggested reading

5. Help in getting job

6. Help in choosing courses

7. Help in choosing major

8. Help in choosing school

9. Letters

10. Telephone conversations

11. Referral to agencies or others in social work

12. Information on financial aid

13. Other (specify)

2Z. Since your first contact with Social Work Careers, which of the following have you done? (Check all that apply)

1. Requested literature about social work

2. Read materials, such as pamphlets, on social work

3. Requested college catalogs

4. Taken courses for better preparation for social work

5. Visited social agencies 
6. Read books on social work

7. Talked with others about social work

8. Applied for admission to a School of Social Work

9. Applied for paid employment in social work

10. Applied for volunteer work in a social agency

11. Other

AAA. How much do you think any of the following would have increased your interest in social work? (Check most appropriate column)

\section{Little}

or None Moderate Much

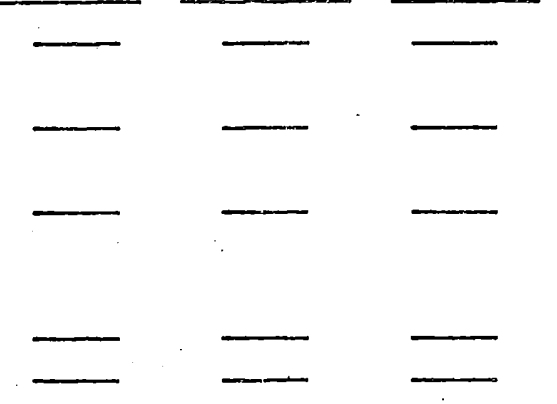

1. Development of private practice

2. Higher salary scales in social work positions

3. More prestige in the designation of the profession than "social work"

4. Legal regulation

5. More social action

BBB. After your contact with Social Work Careers, what factors have discouraged your interest in social work? (Check one or more)

1. Limited admission to School of Social Work

- 2. Length of time for education

3. Interest in another field

- 4. Pay scale

- 5. Adverse social agency experience

- 6. Contact with social worker

- 7. Influence of other people.

- 8. Other (specify) 
APPENDIX-II

SUMMARY OF TESTS OF SIGNIFICANCE BETWEEN

GROUPS AT .05 LEVEL

\begin{tabular}{|c|c|c|c|c|}
\hline Trait & $\begin{array}{l}\text { Samples } \\
\text { Compared }\end{array}$ & $\begin{array}{l}\text { Degrees of } \\
\text { Freedom }\end{array}$ & Chi Squares & $\begin{array}{l}\text { Test } \\
\text { Result }\end{array}$ \\
\hline \multirow[t]{3}{*}{$\begin{array}{l}\text { Undergraduate Major (Social Science/ } \\
\text { all others) }\end{array}$} & SWC/Pins & 1 & .116 & $\mathrm{Ns}^{\mathrm{a}}$ \\
\hline & OC/Pins & 1 & .263 & NS \\
\hline & SWC/OC & 1 & .084 & NS \\
\hline \multirow{3}{*}{$\begin{array}{l}\text { Number of Psychology Courses } \\
\text { Completed }\end{array}$} & SWC/Pins & 2 & 10.442 & $s^{b}$ \\
\hline & $\propto /$ Pins & 2 & .141 & NS \\
\hline & SWC/OC & 2 & 2.123 & NS \\
\hline \multirow{3}{*}{$\begin{array}{l}\text { Number of Sociology Courses } \\
\text { Completed }\end{array}$} & SWC/Pins & 2 & 1.212 & NS \\
\hline & OC/Pins & 2 & 1,212 & NS \\
\hline & SWC/OC & 2 & 1.066 & NS \\
\hline $\begin{array}{l}\text { Previous Work Experience } \\
\text { (Paid/Volunteer) }\end{array}$ & SWC/OC & 1 & 2.148 & NS \\
\hline \multirow{3}{*}{$\begin{array}{l}\text { Time of Awareness of Social Work } \\
\text { as a career (during :high school/ } \\
\text { during college/after college) }\end{array}$} & SWC/Pins & 2 & 13,340 & $s$ \\
\hline & OC/Pins & 3 & .621 & NS \\
\hline & SWC/OC & 2 & 1.233 & NS \\
\hline \multirow{3}{*}{$\begin{array}{l}\text { Time first considered SW as a } \\
\text { career (H.S. / college/after } \\
\text { college) }\end{array}$} & SWC/Pins & 2 & 15.128 & $S$ \\
\hline & $\infty /$ Pins & 2 & .528 & NS \\
\hline & SWC/OC & 2 & 4.897 & NS \\
\hline \multirow{3}{*}{$\begin{array}{l}\text { Time decided on social work as a } \\
\text { career (H.S. / College/after } \\
\text { college) }\end{array}$} & SWC/Pins & 2 & 27.615 & $S$ \\
\hline & $\infty /$ Pins & 2 & .373 & NS \\
\hline & SWC/OC & 2 & 9.031 & $S$ \\
\hline $\begin{array}{l}\text { Reason considered Social Work } \\
\text { as career }\end{array}$ & SWC/Pins & 8 & 17.420 & $S$ \\
\hline \multirow{2}{*}{$\begin{array}{l}\text { Most important function of Social } \\
\text { Work }\end{array}$} & SWC/Pins & 2 & 2. 154 & NS \\
\hline & swC/OC & 2 & 3.257 & NS \\
\hline Method of Social Work concentration & SWC/Pins & 2 & 23.886 & $\mathrm{~s}$ \\
\hline
\end{tabular}

\footnotetext{
a Not Significant

${ }^{b}$ Significant
} 
APPENDIX III

SUMMARY OF TESTS OF SIGNIFICANCE OF TRAITS WITHIN

THE SAMPLE AT THE . O5 LEVEL

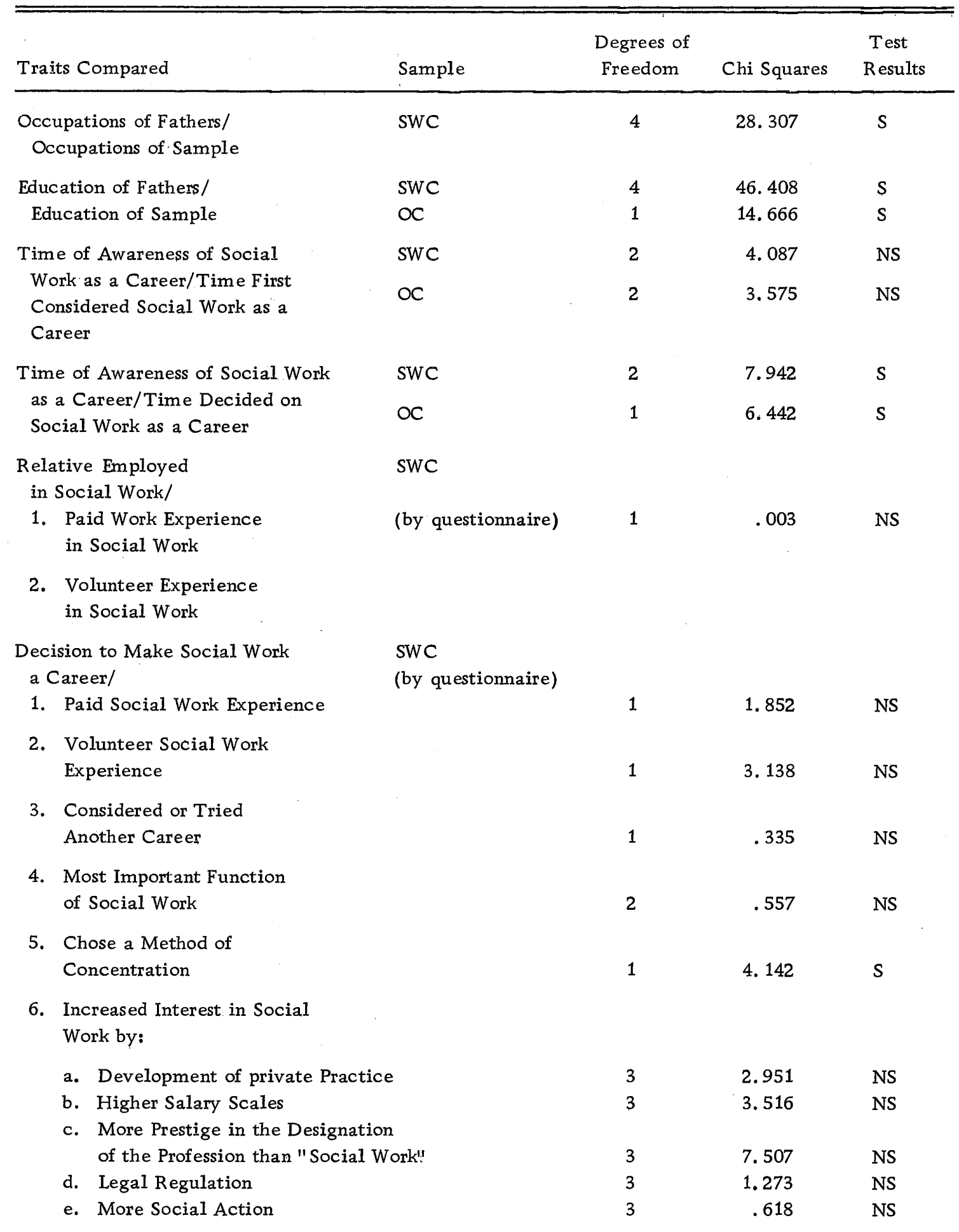


APPENDIX III (Continued)

\begin{tabular}{|c|c|c|c|c|}
\hline Traits Compared & Sample & $\begin{array}{l}\text { Degrees of } \\
\text { Freedom }\end{array}$ & Chi Squares & $\begin{array}{l}\text { Test } \\
\text { Results }\end{array}$ \\
\hline $\begin{array}{l}\text { Degree of Interest in Social } \\
\text { Work/ }\end{array}$ & $\begin{array}{l}\text { SWC } \\
\text { (by questionnaire) }\end{array}$ & & & \\
\hline 1. Highest Grade Completed & & 6 & 14.087 & $S$ \\
\hline 2. Paid Social Work Experience & & 2 & 3.343 & NS \\
\hline 3. Volunteer Work Experience & & 2 & 3.240 & NS \\
\hline 4. Sex & & 2 & 5.641 & NS \\
\hline $\begin{array}{l}\text { 5. Degree of Activity in } \\
\text { School or Community } \\
\text { Organizations }\end{array}$ & & 4 & 5.406 & NS \\
\hline
\end{tabular}

